
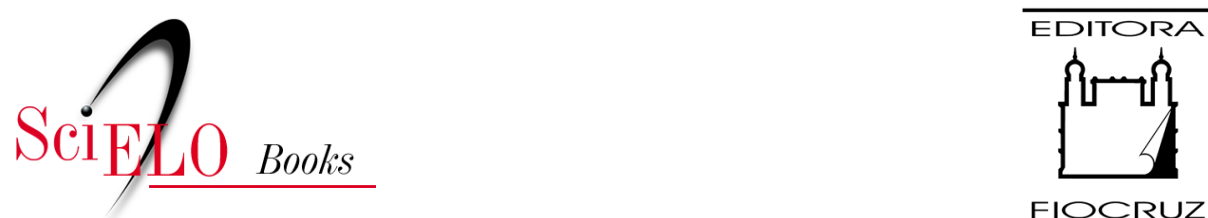

FIOCRUZ

\title{
6. Estratégias de contenção em saúde
}

\author{
Lígia Giovanella
}

\section{SciELO Books / SciELO Livros / SciELO Libros}

GIOVANELLA, L. Estratégias de contenção em saúde. In:

Solidariedade ou Competição? Políticas e sistema de atenção à saúde na Alemanha [online]. Rio de Janeiro: Editora FIOCRUZ, 2001, pp. 247288. ISBN: 978-65-5708-097-9.

http://doi.org/10.7476/9786557080979.0009.

(c) $\underset{\mathrm{ar}}{\mathrm{ar}}$

All the contents of this work, except where otherwise noted, is licensed under a Creative Commons Attribution 4.0 International license.

Todo o conteúdo deste trabalho, exceto quando houver ressalva, é publicado sob a licença Creative Commons Atribição 4.0.

Todo el contenido de esta obra, excepto donde se indique lo contrario, está bajo licencia de la licencia Creative Commons Reconocimento 4.0. 


\section{Estratégias de Contenção em Saúde}

As reformas do Seguro Social de Doença alemão durante os anos de 1990 inșerem-se em processo de contenção de gastos. Desse modo, a 'terceira etapa da reforma da saúde' não pode ser considerada uma 'reforma sanitária' no sentido positivo do termo. Diversos autores qualificam como 'reformas sanitárias' processos político-sociais referentes a mudanças administrativas e organizacionais com o objetivo de produzir impactos positivos em saúde, considerada a atenção à saúde como luta contra a doença e a promoção da saúde de forma ampliada, relacionada aos diversos âmbitos econômicos e sociais de determinaçāo do processo saúdeenfermidade (Berlinguer, 1988; Fleury, 1989; Testa, 1987). ${ }^{308}$ Nesse sentido, reordenaçōes do sistema de saúde, que visam a conter gastos e alcançar maior eficiência econômica, não poderiam ser descritas sob tal conceito.

A maioria das iniciativas de reforma teve como ponto de partida déficits financeiros, colocando em segundo plano problemas diagnosticados na utilização e prestação de açōes de saúde e questões relativas ao estado de saúde da população. Com o propósito principal de estabilização das taxas de contribuição, a estratégia eleita foi a ampliaçāo da competição ao interior do sistema de proteção e atenção à saúde.

A elevação das taxas de contribuição, como discutido anteriormente, esteve relacionada não apenas à dinâmica dos gastos, induzida pela oferta e por mecanismos inadequados de regulação, mas também ao comportamento das receitas. Essas taxas permaneceriam estáveis caso a participaçăo da renda do trabalho assalariado na economia nacional e o nível de ocupação também tivessem sido sustentados em patamar constante, garantindo base de arrecadação compatível. A base de financia-

308 No contexto do 'reformismo', reformas são mudanças positivas nas regras e instituições sociais, previamente planejadas, direcionadas à redistribuição de poder e bens na sociedade e de ampliação da liberdade de participação, em decorrência de acordos entre grupos sociais mais poderosos e outros até então desfavorecidos (Nohlen, 1989; Bobbio, Matteucci \& Pasquino, 1986). 
mento do Seguro Social de Doença sofreu estreitamento resultante da evolução menos positiva da economia e de políticas econômicas neoconservadoras, que levaram a perdas reais dos trabalhadores assalariados $\mathrm{e}$ ao aumento do desemprego.

Se o problema é de receitas, seria preciso ampliar a base de arrecadação, o que defendem setores mais à esquerda, propondo, além do combate ao desemprego, a ampliação da inclusão de todos os trabalhadores e/ou população ocupada, por meio do asseguramento obrigatório, no seguro social, e o aumento do salário limite de contribuição em reforço à solidariedade. A ampliação da base para o cálculo de contribuiçōes teria efeito positivo imediato sobre as receitas, permitindo redução das taxas de contribuiçāo, principal objetivo sempre renovado das reformas. Para outros autores, se o problema é a base da arrecadação, a solução estaria em mudança radical: modificação do modelo de seguro social para um sistema universal financiado com recursos fiscais (Offe, 1990; Mayntz \& Scharpf, 1995). ${ }^{309}$

A terceira etapa da reforma da saúde objetivou, mais uma vez, intervir nesta dinâmica, mas as principais medidas aprovadas estiveram em claro descompasso com os diagnósticos mais apurados sobre o problema da expansāo dos gastos em saúde e de erosão das receitas. Não se dirigiram a soluçōes direcionadas a ampliar a receita (de forma solidária), cuja erosão, embora denunciada e explicada com diferentes ênfases por conservadores e setores de esquerda, é amplamente reconhecida; tampouco resolveram problemas na prestação ou melhoraram controles sobre prestadores e produtores de insumos setoriais.

A discussão realizada no capítulo 4 sobre as causas arroladas para os aumentos das despesas em saúde evidenciou a importância das formas de organização da prestação e de emprego das tecnologias médicas como os principais fatores responsáveis pelo incremento de gastos. As políticas aprovadas na terceira etapa, contudo, nāo tomaram como objeto prioritário estes fatores e sim, como discutido, dirigiram-se a privatizar a demanda.

A terceira etapa, portanto, pode ser caracterizada como neoconservadora, pois teve como objetivo principal a contenção de gastos setoriais. As escolhas realizadas estiveram relacionadas à política econômica e aos interesses empresariais de contenção de custos sociais do trabalho, expressão de uma estratégia de acumulação orientada à melhoria da posição do capital alemāo na competição internacional. O enfrentamento de problemas na organização do sistema e na

309 Nessa perspectiva, o modelo universalista adotado no Brasil seria avançado. Autores que apontam o problema do desemprego como estrutural - mudanças na esfera do mercado de trabalho, não apenas na redução de postos de trabalho, mas também maior rotatividade, períodos mais freqüentes de desemprego etc. - indicam os sistemas universais com base em contribuiçōes fiscais como melhor alternativa à proteção (Offe, 1990; Mayntz \& Scharpf, 1995). Contudo, também para defensores da redução dos custos sociais do trabalho, um sistema universal de base fiscal é apontado para reduzir custos sociais do trabalho e melhorar a posição de competitividade do país (Biedenkopf, 1993). 
qualidade da atenção, quando aventado, esteve subordinado aos propósitos de reduçāo de despesas. Embora impulsionadas pela retórica da eficiência, as principais medidas propostas estiveram direcionadas ao deslocamento de gastos para os pacientes, reduzindo despesas financiadas solidariamente.

Ambas as concepções para a competiçāo - tanto a de "privatização da demanda' como a de 'concorrência da oferta' - presumem a estabilizaçāo das taxas.de contribuição, o que implica dizer que visam ao controle de gastos, lembrando, porém, que sob perspectivas distintas e com repercussões opostas sobre a eqüidade do sistema. Enquanto os atores que formulam a concepção da 'concorrência da oferta’ fazem diagnóstico amplo sobre problemas da estrutura de atençāo e recomendaçōes abrangentes para a reorganização da oferta, as medidas aprovadas na terceira etapa pela coalizão conservadora-liberal enfatizaram restriçōes, optandose por medidas de controle da demanda e a introdução de mecanismos de mercado, deslocando-se gastos para os segurados.

O objetivo reiterado das políticas de contenção tem sido o aumento da eficiência: o emprego ótimo/racionalizado de recursos. O termo eficiência, contudo, ế empregado com diferentes significados, podendo corresponder a propósitos diversos, como ocorre com as concepções da competição. Quando se trata de políticas de contenção, com foco em cortes e restrições, o presumido alcance de maior eficiência resulta menos de melhor emprego dos recursos e mais da redução dos meios empregados, por intermédio do deslocamento de gastos para os usuários, e, com isso, em diminuição de gastos públicos.

É necessário portanto diferenciar contenção de gastos de reduçāo de custos. Custos referem-se aos preços unitários dos produtos e sua redução teria o sentido de maior eficiência, quer dizer, de conseguir gerar um produto com emprego de quantidade menor de recursos. Por sua vez, contençăo de gastos implica, na maioria das vezes, em cortes de despesas, ocorrendo uma redução dos gastos totais mais em conseqüência da diminuição do número de produtos distribuídos do que do alcance de maior produtividade. A contenção de gastos, todavia, coage à contenção de custos, podendo ocorrer paralelamente aos cortes de gastos e à reduçāo de custos.

O esclarecimento a respeito dos significados do termo eficiência é importante; pois, hipoteticamente, racionalizar o emprego de recursos poderia contribuir para o alcance de maior efetividade e de níveis mais elevados de garantia da atenção, sendo assim, objetivo sempre almejado. Contudo, quando o alcance de maior eficiência torna-se o objetivo 'principal', ele elude os propósitos de contenção de gastos. Isto é, alcançar maior eficiência por meio de melhor aplicaçāo de recursos é objetivo imprescindível para se atingir melhores níveis de atenção, ainda mais quando os recursos são escassos, como no caso do Brasil, onde tanto os recursos alocados são baixos, quanto sua aplicação apresenta problemas; entretanto, tomado como objetivo em si, pode resultar apenas em contenção. 
As estratégias de contenção impulsionadas pela coalizão conservadora-liberal durante os anos de 1990 na Alemanha tiveram como eixo a ampliação da competição no setor saúde, articulada a uma série de medidas, as quais, em sua maioria, podem ser ordenadas como de 'racionalização da demanda', além de outros mecanismos de 'racionalizaçāo de oferta', classificaçāo empregada para a qualificação de medidas de contenção/promoção da eficiência. Entre as primeiras, destaca-se o copagamento como principal mecanismo restritivo, e entre as segundas, inovações na organizaçāo da atenção, pelas suas potencialidades em imprimir nova direcionalidade ao modelo assistencial no sentido de uma atenção integrada e integral.

\section{Competição}

A crítica à ampliação da competição no seguro social de doença (GKV) não se esgota na crítica ao modelo de competição do governo conservador. Fundamentalmente, a competição é incompatível com o princípio de solidariedade que rege o sistema, pois em situação de competição, o que move os participantes são os ganhos econômicos.

A lógica da competição é a seguinte: colocadas as Caixas em relaçōes competitivas, estas procurarão tornar-se atrativas ao máximo para aqueles segurados que signifiquem maiores ganhos, mais saudáveis e melhor remunerados, e, ao mesmo tempo, evitarão ao máximo aqueles que apresentem maior risco de adoecer ou com morbidade mais elevada. Nesse caso, o objetivo de melhoria da qualidade da atenção tem seus valores invertidos, em especial na atenção a pacientes crônicos. A necessária definição de grupos de riscos para uma melhor atenção, aos quais devem ser oferecidas ações concentradas de prevenção e diagnóstico precoce, não tem correspondência com a lógica que os exclui e seleciona negativamente.

Por meio da competição, tende a ocorrer a privatização e a seleção de riscos, uma vez que, para garantir menores preços no mercado, os estímulos são para que se cobre mais dos grupos de maior risco e se amplie a participação direta dos pacientes. As desigualdades nas chances de adoecer e de oportunidades em decorrência do estado de saúde já existentes tendem a ser sedimentadas ou aprofundadas, ao mesmo tempo em que se quebra a solidariedade entre saudáveis e doentes (Gerlinger \& Stegmüller, 1995a).

Diversas características do bem 'saúde' fazem com que os mecanismos de mercado não sejam adequados ao controle de sua prestação e distribuição, tornando imprescindível a regulação estatal (Donaldson, \& Gerard, 1992) ${ }^{310} \mathrm{Em}$ ter-

\footnotetext{
310 Algum tipo de intervenção estatal ocorre em grande parte dos mercados, seja por meio de subsídios aos consumidores ou fiscalização dos produtores, como é, por exemplo, o do setor de alimentos. Mas as características do bem saúde fazem com que a intervenção estatal deva ser mais ampla do que em outros mercados.
} 
mos morais, pode-se considerar saúde como um bem especial, bem de mérito, que não deveria ser comprado ou negociado no mercado, pois não existe mercadoria equivalente para a satisfação da necessidade saúde. ${ }^{311} \mathrm{O}$ meio de troca, o dinheiro, equipara diferentes qualidades, quantificando-as. Saúde, porém, não é bem quantificável.

Nos tratados de economia da saúde são assinaladas tradicionalmente diversas especificidades do bem saúde que tornam o mercado setorial imperfeito: a assimetria de informações entre prestadores e consumidores; as externalidades que ocasiona - o não cuidado da saúde de um pode trazer malefícios para os outros, da mesma forma que o cuidado individual pode trazer vantagens para o grupo -; a inelasticidade da demanda para situações graves - por se tratar da sobrevivência, esta năo diminui com o aumento de preços e o demandante está disposto a alocar o máximo que puder disponibilizar - a imprevisibilidade da demanda do ponto de vista individual, entre outros (Donaldson \& Gerard, 1992; Iunes, 1994; Arrow, 1963). Além disso, não há garantia de resultados; o produto nāo pode ser devolvido nem o serviço refeito.

As relações entre oferta e procura no setor saúde apresentam particularidades que as distinguem de outros mercados. Em virtude da predominância dos prestadores - em particular, os médicos -, não pode ocorrer o suposto equilíbrio das interações entre oferta e procura. Menos ainda, vigorar a soberania do consumidor. Especificidades do bem saúde fazem com que grande parte da demanda seja definida pelo prestador e não pelo consumidor. Na qualidade de consumidores, a demanda (primária) dos pacientes por ações de saúde é inespecífica, vindo a ser de fato definida mediante aconselhamento do médico: 'demanda induzida pelo prestador' (Evans; Cromwell \& Mitchel apud Donaldson \& Gerard, 1992).

Os médicos dominam o sistema de saúde como nenhum outro grupo em seu ramo específico (Reiners, 1996). Detêm socialmente o direito e a liberdade de abordar o sofrimento de acordo com seu conhecimento, podendo decidir, em grande parte, a demanda pelos serviços que irão prestar. Além disso, a demanda por ações de saúde, avaliadas as necessidades de saúde, é inelástica em relação aos preços, uma vez que a necessidade de consumo não cresce diretamente com a redução de preços nem diminui com preços crescentes, tendo-se em mente que a necessidade de tratamento médico independe dos preços. Assim, o sistema de saúde não pode ser regulado ou conduzido pelos mecanismos da oferta e procura.

Esta posição dominante dos prestadores expressa-se não apenas em nível individual, na relação médico-paciente, mas também na relaçāo médicos-caixas. Desse modo, a eliminação da predominância da oferta, ou seja, a desigualdade nas

3ı Contudo, na interpretação econômica clássica, a assistência médica é considerada como um bem privado, uma vez que "é um serviço que beneficia a pessoa que o consome e que uma vez consumido por uma pessoa, não o pode ser por outras" (Almeida, 1998:41). 
relações de poder entre Caixas e prestadores de serviços é pressuposto importante para a contenção mais efetiva de gastos, dado que os prestadores têm grande influência nessa definição. É difícil, porém, que esta seja alcançada por meio de mecanismos que estimulem a competição entre as Caixas como aqueles propostos pela coalizão conservadora-liberal. Somente ao final da década, com a Lei da Reforma do Seguro Social de Doença 2000, após a mudança de governo, foram introduzidas medidas com potencialidade de fortalecer a posição das Caixas frente aos prestadores de serviços.

Outro perigo introduzido pelo aprofundamento da competição é o distanciamento ainda maior entre a atuação das Caixas e os objetivos em saúde. Com a escolha da competição, os gastos precisam ser aferidos de acordo com o ponto de vista da amortização dos riscos a curto prazo, o que resultará no baixo interesse na implementação de medidas preventivas, cujos rendimentos só podem ser contabilizados a longo prazo.

Ao contrário do suposto pela coalizão governamental conservadora-liberal e apregoado por defensores de cortes nos setores sociais, maior competição ou a vigência de mecanismos de mercado não configuram garantias de oferta de preços mais baixos. Exemplo maior disto são os altos gastos em saúde nos EUA, onde os mecanismos de mercado são muito difundidos (Behrens et al., 1996; Stone, 1996). ${ }^{312}$ Com base na experiência norte-americana, diversos autores demonstram a inadequaçāo dos mecanismos de competição para alcance de maior efetividade, eficiência e capacidade inovadora do sistema de atenção à saúde (Morone, 1996; Stone, 1996; Schlesinger, 1996).

Com o aumento da competição entre Caixas, cortes de açōes nāo rentáveis, nem por isso menos importantes, ou a introdução de outras mais caras, às vezes necessárias, são alteraçōes mais fáceis de ocorrer do que o alcance de maior eficiência (Gerlinger \& Stegmüller, 1995a). Além disso, a concorrência por segurados faz crescer de modo desproporcionado os custos de administraçāo e marketing, o que atenta contra a eficiência (Reiners, 1996). ${ }^{313}$ Igualmente, nāo é possível deixar de notar que a qualidade pode ser descurada na pressão da concorrência por menores preços (Nolan, 1996). Um catálogo de serviços único não é suficiente para a manutenção da qualidade. $\mathrm{O}$ segurado, transformado em consumidor no mercado da saúde, tem poucas condiçōes para avaliar a qualidade dos serviços prestados.

3 I2 Nos EUA, apenas $20 \%$ da populaçăo é coberta por esquema público de proteçăo à saúde (Medicare), federal para velhos, (Medicaid), federal/estadual para pobres e champus para empregados públicos federais (Stone, 1996).

$313 \mathrm{O}$ aumento dos gastos administrativos pode ser bem observado quando se compara a diferença entre gastos administrativos do seguro público e dos seguros privados, como apresentado no capítulo V. Com a ampliação da competiçāo, as Caixas buscam estratégias de marketing inovadoras a fim de se tornarem mais atraentes. O atual slogan das Caixas Locais (AOK) é 'Caixa da Saúde', em contraposição à denominação literal das Caixas, que é 'Caixas de Doença'. A nova denominaçĩo busca vender a imagem de quem promove saúde e garante oferta ampla de cursos educativos. 
Dado o grau de imperfeição do mercado de atenção à saúde, ${ }^{314}$ mecanismos de competição são reconhecidamente pouco adequados a este setor. Um funcionamento 'adequado' deste mercado pressupõe extensiva intervenção estatal (Donaldson \& Gerard, 1992). É a intervenção estatal que garante o funcionamento do mercado e não a competição. O Estado deveria intervir gerindo a competição por meio de mecanismos de condução, incentivos e subvençōes (Morone, 1996:53).

O reconhecimento de que um livre mercado em saúde não pode funcionar tem levado à difusão de proposiçōes de gerenciamento da competição. As forças de mercado seriam empregadas no âmbito de regras cuidadosamente desenhadas (Enthoven, 1993 apud Schlesinger, 1996). Mas não com o objetivo de negar o mercado. Ao contrário, buscam possibilitar o funcionamento do mercado da saúde. $\mathrm{O}$ 'bem especial saúde', por meio destes mecanismos, deveria transformar-se em bem de consumo qualquer.

A competição entre as Caixas na Alemanha é condicionada por intensa regulação estatal, todavia, distancia-se da competição administrada (managed competition), formulada para regular mercado de seguros privados de saúde. Conforme a formulação clássica de Enthoven (1993 apud Ugá, 1997), o ponto central, da managed competition, é a idéia de competição regulada publicamente entre provedores de seguros-saúde, os quais deveriam garantir asseguramento de modo a preencher critérios mínimos de abrangência de açōes e benefícios assegurados, qualidade dos serviços e base financeira. Em um mercado competitivo gerenciado, as seguradoras procurariam oferecer os melhores produtos e apresentar os menores preços possíveis para vender o máximo de seguros. As seguradoras concorreriam entre si, ofertando produtos atrativos para os consumidores e oferecendo preços baixos (prêmios), que os consumidores pudessem pagar. Por sua vez, os consumidores de planos de saúde seriam movidos por um cálculo de utilidade máxima, escolhendo os planos de saúde mais baratos (Enthoven e Kronick apud Stone 1996 e apud Almeida, 1995).

A proposta alemã aproxima-se do modelo de 'competição gerenciada' por objetivar, assim como neste modelo, alterar o comportamento dos segurados (Schlesinger, 1996), no sentido de que busquem filiar-se aos seguros menos onerosos. Diferencia-se, contudo, da managed competition, pois um elemento central da reestruturação da demanda neste esquema é o papel atribuído a um terceiro agente, principal responsável por esta reestruturação. No modelo de competição administrada, a demanda previamente pulverizada é reestruturada por meio da

314 Nenhum mercado é perfeito, de acordo com um conjunto de características ideais - certeza, ausência de externalidades, conhecimento perfeito, consumidores que podem agir livremente conforme os seus interesses e presença de numerosos e pequenos produtores em iguais condições de competição. O que ocorre com o mercado em saúde é que 'nenhum' destes pressupostos ideais funciona adequadamente (Donaldson \& Gerard, 1992). 
introdução de um terceiro agente, que intermedia as relaçōes entre as seguradoras e os clientes potenciais, concentrando-os em grandes grupos mais informados e com maior poder de barganha (Ugá, 1997). ${ }^{315}$

No caso alemão, os contribuintes devem agir individualmente, mudando de Caixa movidos pelos preços ofertados (taxas de contribuição diferenciadas). Mais do que isso, a competiçāo entre as Caixas na Alemanha diferencia-se fundamentalmente deste modelo, por tratar-se de esquema público redistributivo, sendo seus âmbitos de regulação da competição muito mais abrangentes - o catálogo de açōes garantidas é completo e a compensação financeira da estrutura de riscos previne a seleção de riscos.

O exemplo dos EUA permite também identificar os problemas que a competição introduz e as diversas estratégias utilizadas pelas seguradoras para manter seus preços baixos: entre outras, a negociação de preços com seus prestadores médicos e hospitais -, a cobertura pela apólice restrita apenas a açōes tidas como absolutamente necessárias e por meio da participação financeira dos pacientes. Todos esses esquemas podem reduzir preços, contudo, a principal estratégia empregada pelas seguradoras para a redução dos preços dos seguros é 'a seleção de riscos' (Stone, 1996).

Se o empresário de planos de saúde pode escolher previamente os segurados que produzirão poucos gastos quando possuidores da apólice, aumentará com isto os lucros visados. Selecionados os riscos, a inclusão de grupos de risco mais elevado vai depender do pagamento de prêmios mais altos ou da exclusão de determinadas doenças da apólice e, com mais freqüência, de afecçōes com início anterior à compra da apólice. A seleção de riscos em casos extremos significa a recusa do asseguramento, a rejeição do postulante.

É pouco provável, no entanto, que venha a ocorrer semelhante seleçāo de risćos na Alemanha. Além da baixa aceitação, diversos mecanismos de regulação funcionam como barreiras para impedir que isto possa acontecer. As Caixas são legalmente proibidas de indagar a respeito do estado dé saúde dos pretendentes a contribuinte e de incluir cláusulas de exclusão de doenças prévias ou de doenças em geral em seus contratos. O principal mecanismo que previne a seleção de riscos é a compensação financeira da estrutura de riscos (RSA). Estas transferências financeiras entre Caixas reduzem os estímulos para a seleção de riscos, uma vez, que suas receitas com segurados com riscos relativamente mais baixos e renda proporcionalmente mais altas serão redistribuídas para Caixas com contribuintes com riscos relativamente mais altos e renda mais baixas.

31.5 Este foi o modelo proposto pelo governo Clinton para a reforma nos EUA. Nesse país, as organizações de manutenção da saúde, Health Maintenance Organisations (HMOs) denominaçāo sob a qual são agrupadas diferentes formas de mix de provisão de seguros e organização de serviços, corporilicam as estratégias de managed competition e managed care de forma articulada. 
Desse modo, os efeitos da competição entre as Caixas por segurados serão atenuados consideravelmente pelo mecanismo de compensação financeira da estrutura de riscos criado pela Lei da Estrutura da Saúde (GSG). Este mecanismo, considerado o pressuposto fundamental para competição não destrutiva, 'núcleo técnico da nova ordem competitiva' (Jacobs \& Reschke, 1994), refreia, ainda que não completamente, a competição predatória entre as Caixas. A introduçāo da compensação financeira da estrutura de riscos teve por meta a promoção da igualdade de condições para o início da competição. Esta igualdade, porém, não é totalmente garantida, pois os critérios selecionados para a compensaçāo não dão conta da equiparação completa dos riscos. O diferente risco de adoecer foi indiretamente contemplado por meio dos critérios de idade e sexo, mas a estrutura real de morbidade dos segurados não foi diretamente levada em conta. É difícil, portanto, estimar em que medida o esquema de compensação financeira da estrutura de riscos implementado na Alemanha dá conta de tornar as vantagens financeiras decorrentes da seleção de riscos pouco atraentes, isto é, compensa realmente o diferencial de riscos. ${ }^{316}$

Além disso, a manutenção da coexistência de diferentes bases geográficas para cálculo de taxas de contribuição - regionais, para a maioria das Caixas, e nacional, para as Caixas Substitutas - produz vantagem para as últimas, pois possibilita que diversidades de gasto regionais sejam compensadas entre o conjunto dos segurados, mantendo taxas de contribuição mais baixas, enquanto as outras Caixas não têm esta possibilidade. Além disso, a definição da compensação de riscos de modo separado para as Regiōes Ocidental e Oriental colocava as últimas em situação de desvantagem. Esta situação será equacionada com a unificação progressiva (2001-2007) da compensação financeira da estrutura de riscos (RSA) entre as Regiões Ocidental e Oriental, definida pela Lei para Adaptação do Direito no GKV de dezembro de 1999.

As Caixas em competição, contudo, estarāo pressionadas à seleção de riscos, pois esta é a estratégia mais eficiente de conter preços e, com isso, atrair mais clientes. Estratégias indiretas de seleção de riscos podem vir a ser empregadas, bem como estratégias diferenciadas de marketing para atrair contribuintes jovens.

Outra estratégia dos provedores de seguros em competição é a difusão de normas de distribuição compatíveis com o funcionamento do mercado, por meio de propaganda e marketing, para convencer a opinião pública de que o asseguramento deve ser bem de consumo e nâo um direito social e que os mais saudáveis e bem posicionados não têm obrigação social ou moral em contribuir para a proteção dos menos favorecidos (Stone, 1996). As normas de justiça

316 Estudos mostram que sistemas de compensação de riscos, mesmo quando fundamentados em análises multivariadas, conseguem prever apenas $20 \%$ da variaçāo dos gastos que realmente ocorrem (Newhouse apud Stone, 1996). 
distributiva em um mercado e no seguro social são totalmente diversas. Em mercado competitivo, bens e serviços são distribuídos de acordo com a capacidade de compra dos indivíduos. A demanda nada mais é do que a disposição e capacidade das pessoas para pagar alguma coisa. No mercado, ninguém tem o direito moral de possuir algo que não possa ou queira pagar. A proteção social e o Seguro Social de Doença, em particular, visa exatamente a contrapor-se a este mecanismo de distribuição do mercado, garantindo bens, serviços e ajuda financeira independente da capacidade de pagamento dos indivíduos.

Embora o Seguro Social de Doença alemão tenha tradição solidária forte, que se expressa inclusive na utilizaçāo freqüente do termo solidariedade pelo cidadão comum (Ulrich, 1996), a ampliação de mecanismos de mercado ao interior da proteção pode afetar esta tradição não somente pelo estímulo à seleção de riscos que representa, mas também pela difusão de valores distintos daqueles da solidariedade. As seguradoras (Caixas) em competição podem vir a estimular os segurados a buscar menores preços e, ao mesmo tempo, divulgar que os relativamente mais sadios podem conseguir menores preços, caso se afastem dos relativamente mais doentes. Difundiriam, assim, normas de distribuição de mercado, reforçando concepçōes de eqüivalência, incompatíveis com aquelas da solidariedade. ${ }^{317}$

Outra estratégia utilizada nos EUA pelas seguradoras em competição para alcançar preços mais baixos são os modelos de atenção administrada, managed care. Na concepção de Stone (1996), o modelo de managed care foi uma das estratégias empregadas pelas seguradoras em competição para redução de suas despesas com a atenção prestada, seja ela médica, hospitalar ou farmacêutica. Seria a contrapartida da 'competição gerenciada' que, ao contrário, visa a alterar o comportamento dos segurados (Schlesinger, 1996). Segundo Ugá (1997:124), “o modelo de managed care reorganiza a oferta de serviços de saúde, enquanto o esquema de managed competition reestrutura a demanda".

Nos EUA, em um sistema de managed care, a maioria das decisōes dos médicos acerca de internações e medicamentos passa a ser vigiada, o que significa importante controle sobre os próprios médicos. $\mathrm{O}$ médico geral funciona como porta de entrada do sistema (gatekeeper), decidindo sobre os encaminhamentos para especialistas e internaçōes hospitalares. Decisāo sobre a qual o pessoal administrativo da seguradora também intervém. Por este meio, os funcionários do seguro têm a última palavra a respeito de qual o tratamento a realizar ou o procedimento a solicitar.

Uma característica central do managed care é a revisão prospectiva da solicitação do médico $\mathrm{e}$ a autorização ou recusa para a realização de um procedimento, o que é problemático, porque o médico perde a autoridade para qualquer

317 Nos EUA, segundo Stone (1996), as seguradoras fizeram campanhas de propaganda de massa para convencer a população de que ninguém tem o dever moral de pagar pela doença de ninguém. Um anúncio mostrava um trabalhador da construção civil em um andaime, com os seguintes dizeres "Se você não corre nenhum risco, por que pagar pelo risco dos outros?". 
decisāo clínica afora as rotinas estabelecidas, o que pode atentar contra a qualidade da atençāo. A intervenção direta da seguradora, com o objetivo de controlar as despesas médicas ao máximo possível, pode resultar em restrições da assistência que afetam a qualidade da atenção e em prejuízos ao doente em termos de cura ou alívio do sofrimento. Se as seguradoras estão sob pressão para reduzir custos, garantir lucros e oferecer prêmios competitivos, a qualidade dos cuidados pode sofrer, em particular, naqueles aspectos que não podem ser diretamente observados pelos pacientes (Nolan, 1996).

Para Morone (1996), os mecanismos de 'atenção gerenciada' (managed care) produziram importantes mudanças no mercado de saúde nos EUA. A competição levou a um processo de concentraçāo vertical - seguradoras assumiram o setor de prestação - e de concentração horizontal não apenas do setor de seguros privados, mas também da propriedade dos serviços médicos, englobando os diversos setores de atenção e constituindo novo complexo médico-industrial (Relman; Starr apud Almeida, 1995). A acumulação setorial foi propiciada, tendo sido constituídas grandes empresas médicas que negociam ações na bolsa a valores crescentes e que possuem poderoso setor administrativo (Morone, 1996).

Nesse sentido, um dos resultados da competição entre Caixas que já se pode observar é o processo recente de fusão de Caixas, tornando-as cada vez maiores. Caixas pequenas têm menor probabilidade de sobrevivência na competiçāo. A fusāo pode reduzir custos administrativos e, ao garantir um grupo maior de segurados, permite uma composição mais adequada de riscos. ${ }^{318}$

Embora as Caixas não sejam empresários cuja ação é orientada pelo lucro, têm interesse na própria sobrevivência como organização. O processo de concentração das Caixas por meio de fusões, ocorrido nos últimos anos, contribui para fortalecer esta tendência. Quanto maior a Caixa, tanto maior o capital e número de postos de trabalho em jogo. Os interesses de suas burocracias pela sobrevivência das Caixas como organização as impulsionarão a tentar garantir e/ou ampliar a sua fatia no mercado pela oferta de menores preços, cuja possibilidade envolve a formulação de estratégias similares às acima apontadas, procedimentos estes que atentam contra os princípio da solidariedade.

A competição direciona a alocação de recursos em saúde para grupos com maior capacidade de pagamento, mais bem informados acerca das possibilidades de utilizaçāo, com maior capacidade de articulação e, ao mesmo tempo, que apresentem o mais baixo risco de adoecer (Kühn, 1995a). Deste modo, se as estratégias de mercado das Caixas por menores preços funcionarem, nāo se poderia ainda descartar a possibilidade de ocorrer a longo prazo uma estratificação das mesmas segundo o nível de risco e morbidade. A existência de tal estratificação não é

318 Nos EUA, calcula-se que uma Health Maintenance Organization (HMO) deva ter cerca de 50 mil membros para sobreviver (Clement apud Almeida, 1995). 
certamente novidade no Seguro Social de Doença alemão, uma vez que, pela tradição, as Caixas tinham clientelas fechadas adscritas por profissāo, o que tem certa correlação com o risco de adoecer. A competição anteriormente existente entre Caixas Locais e Substitutas, pela adesão dos 'empregados' e segurados voluntários, já denotava este tipo de estratégia para atrair segurados de baixo risco e rendas altas.

Vale portanto lembrar que a competiçāo nāo é total novidade para o GKV (Stone 1980; Light, 1985; Wynsong \& Abel, 1990). Para Knieps (1997), a tensão entre competição e solidariedade seria constitutiva do sistema. A concorrência entre as Caixas por contribuintes saudáveis teria provocado problemas de condução no GKV, assim como a monopolização ou cartelizaçāo dos prestadores. O estabelecimento de diferentes contratos por tipo de Caixa com prestadores, nos quais eram definidos distintos valores monetários para remuneração das unidades de serviço, em nível estadual, foi uma das formas com as quais a competição entre as Caixas se realizou, trazendo efeitos indesejados, especialmente a elevação de preços no setor ambulatorial.

A partir da introdução da compensação da estrutura de riscos, esta prática foi desestimulada, pois a mesma teria repercussão direta de aumento das taxas de contribuição. Estes efeitos de concorrência entre Caixas Substitutas e Locais na evolução do valor monetário dos pontos para remuneração da atenção ambulatorial exemplifica possíveis resultados deletérios da competição: ocorreu inflação e não redução de preços, como preconizam os defensores de maiores estímulos à competição.

Outro dos resultados da competição pelo lado da oferta pode ser bem ilustrado pelo exemplo do que sucedeu em virtude da concorrência crescente entre os médicos. Houve aumento contínuo do número de ações prestadas por cada médico na tentativa de manter sua parcela de participação no mercado, dado que o número destes tem aumentado continuamente, enquanto o número de segurados se mantém relativamente estável.

A introdução de mecanismos de competição em sistemas de proteção social à saúde não é novidade alemã. Durante a década de 80 , mecanismos de concorrência foram implementados em diversos países, afora os EUA, que até hoje nāo dispōem de sistema abrangente de proteção ao risco de adoecer e desenvolveram vários mecanismos de mercado, que encontram grande difusão. Esses mecanismos são diversos, ainda que tenham por base uma concepção geral semelhante, a de que mecanismos de mercado poderiam conter gastos e produzir maior eficiência na prestação de serviços. Resultam tanto de escolhas políticas distintas como do arcabouço institucional e formas diversas de organização da atenção prévias.

Assim, a reforma alemã diferencia-se tanto do modelo britânico de competição para o estabelecimento de um 'mercado interno', como do modelo sueco de 'competição pública' e da Reforma holandesa. $\mathrm{O}$ modelo britânico de mercado interno tem por base, essencialmente, a separação entre financiamento e prestação 
de serviços até então sob responsabilidade única, passando a ser estabelecidos contratos entre as autoridades financiadoras e os prestadores: "A essência do conceito está na distinção nítida entre o papel de produtor da atenção sanitária (prestador) e o de comprador de serviços médicos, mas ambas as atividades continuam a ser desenvolvidas no âmbito público, ainda que por atores bem diversos" (Almeida, 1995:140). A competição se daria entre os prestadores, em especial, os hospitais, que são públicos na grande maioria, pelos recursos públicos que lhes seriam destinados conforme o poder de atração de pacientes.

O modelo sueco, por sua vez, de 'competiçāo pública', como o nome indica, é uma forma de competiçāo principalmente entre prestadores públicos. A operaçāo e a propriedade das instituições prestadoras permanece pública e o paciente desfruta de livre escolha de médicos e outros prestadores. Os orçamentos são flexíveis, ligados às parcelas do mercado atendidas por prestador avaliado individualmente (Saltman \& von Otter, 1992). A proposta de 'competição pública' relaciona a remuneração das diversas organizações prestadoras a sua capacidade de atrair pacientes, aumentando a influência dos mesmos na prestação e concentrando esforços relativos a mudanças nos serviços (Almeida, 1995). A competição dar-se-ia não por recursos financeiros, mas por parcelas do mercado atendido. $\mathrm{O}$ modelo objetivaria alcançar simultaneamente: alto padrão de atendimento ao cliente para os pacientes, eficiência econômica e responsabilidade social. Além da competição entre prestadores, o modelo propõe mudanças internas aos serviços, buscando democratizá-los mediante técnicas de planejamento participativo no intuito de aproximá-los aos interesses de seus clientes (Burkitt \& Whyman, 1994). ${ }^{319}$

$\mathrm{Na}$ Alemanha vige clara separação entre prestadores e financiadores, pois as Caixas não dispōem de serviços médicos próprios e contratam médicos e hospitais. Os hospitais, mesmo sendo predominantemente públicos, têm seus custos correntes financiados pelos serviços produzidos. As Caixas compram serviços de prestadores contratados: públicos, filantrópicos, privados. Os prestadores, mesmo públicos, só prestam serviços mediante a garantia de pagamento.

A competiçăo proposta na Alemanha, nas reformas dos anos 90 , não foi tanto entre prestadores, mas entre provedores de seguro social, as Caixas. Nesse sentido, seria mais próxima da reforma holandesa, país no qual a proteção também está fundamentada em modelo de seguro social. ${ }^{320} \mathrm{Na}$ reforma holandesa foi

319 A proposta de competição pública foi formulada pelo partido social-democrata sueco e apresenta preocupação com eqüidade, além de buscar enfrentar deficiências do serviço público no que concerne à garantia de maior satisfação da clientela atendida, personalizando mais os serviços prestados.

320 O sistema holandês, contudo, é bem diferente do alemão. É constituído por três tipos de seguro e cerca de $35 \%$ da população é assegurada privadamente. Antes da reforma, as taxas de contribuição de todas as Caixas eram fixadas por lei e já thes era permitido oferecer catálogos opcionais. Para os seguros privados foram instituídas apólices-padrāo, além de também estarem incluídos na compensação linanceira da estrutura de riscos. 
proposta uma forma de 'competiçāo gerenciada', que deveria envolver tanto seguradoras como prestadores de serviços. A reforma objetivou estabelecer a competição entre todas as seguradoras, tanto as Caixas de Seguro Social quanto os seguros privados. ${ }^{321}$ Definiu uma diferenciação na cesta, possibilitando a introdução de cesta opcional. Estratificou a proteção, dividindo o asseguramento em básico obrigatório, financiado solidariamente, e outro complementar, pago apenas pelo segurado. Além disso, as seguradoras poderiam contratar seletivamente os prestadores, o que promoveria competição entre eles, estimulando-os a oferecer melhores preços (Nolan, 1996; Müller, 1996).

Esta modalidade de competição, conquanto envolva instrumentos complexos de regulação, assume, no caso de ser totalmente implementada, ${ }^{322}$ a privatização do risco de adoecer ao assegurar o financiamento solidário para apenas parte da proteção. ${ }^{323}$ No caso alemão, embora esteja aberta a possibilidade de privatização parcial por meio de mecanismos indiretos e apesar de os valores de co-pagamento terem sido majorados, manteve-se o catálogo único, sem restriçōes no que tange à assistência médica, financiado solidariamente. $\mathrm{Na}$ Alemanha a competição é pública, ocorre apenas entre as Caixas do seguro social, diferente da Holanda, onde as seguradoras privadas estāo incluídas na competição e no esquema de compensação de riscos, o que abriria a possibilidade de maior privatização.

\section{'P pivatização da Demanda'}

\section{Privatização parcial dos riscos de adoecer por meio do co-pagamento}

O termo co-pagamento (Selbstbeteiligung) significa que segurados de um sistema no qual o acesso é direto, afora contribuírem para o scguro social, participam diretamente dos custos das prestações sanitárias individuais com valor monetário fixo por tipo de prestação ou percentagem predefinida sobre o valor das

321 A reforma foi formulada pelo governo conservador sob o comando de um empresário.

322 A reforma ainda não foi completamente implementada, pois seus diversos estágios deveriam ser aprovados pelo Parlamento, tendo sofrido modificações. Em 1996, o seguro específico para auxílio-doença foi abolido, tendo os empregadores assumido o pagamento do auxíliodoença por até um ano, no valor de $70 \%$ do salário e a junção dos outros dois ramos do seguro-saúde foi abolida, tendo-se voltado atrás nesta etapa da reforma. O catálogo foi reduzido (Mülter, 1996).

323 A contribuição, porém, é paga em grande parte pelo empregador. Em 1996, a contribuição era de $7 \%$ do salário limite de contribuição, mas $6 \%$ eram pagos pelo empregador (Müller, 1996). 
prestações contratadas pela Caixa. ${ }^{324}$ Isto é, co-pagamento é entendido como pagamento direto pelo paciente de parcela de gastos decorrentes da utilização de serviços, pois os segurados sempre participam indiretamente do financiamento das ações por meio de suas contribuições mensais. ${ }^{32.5}$

A introdução do mecanismo de co-pagamento tem dois objetivos. Um, considerado subalterno, seria o alívio financeiro do sistema ocasionado pelo aporte monetário que proporciona, e o outro, principal, de condução da demanda, de controle da utilização.

Entre as medidas de contenção, o co-pagamento é classificado como forma de racionalização do comportamento dos usuários por intermédio da instituição de taxa moderadora. Parte-se do princípio de que a participaçāo direta nos gastos com saúde poderia conduzir a mudanças no comportamento dos consumidores. Os indivíduos reduziriam utilizaçōes desnecessárias e valorizariam mais o que consomem. O comportamento dos usuários seria alterado especialmente em situações em que não há risco de vida e na utilização de formas alternativas de atenção, situações em que haveria elasticidade da demanda em relação aos preços (Ulrich, 1996; Riege, 1993).

Ao definir mecanismos de co-pagamento, o legislador defronta-se com um dilema. Ou os valores são tão baixos que nāo influenciam nos dispêndios do sistema ou, no caso de serem capazes de produzir contenção de gastos, tão altos que provocam repercussões sociais - efeitos redistributivos e sanitários problemáticos - ao transferir gastos para os orçamentos familiares. A principal questāo em relação à introdução do co-pagamento está, portanto, na possibilidade de instituir um sistema que, ao mesmo tempo, produza diminuição de gastos e seja socialmente suportável ou justo.

Contudo, efetividade de condução e suportabilidade social são comprovadamente incompatíveis para este mecanismo. Diversos autores consideram ser impossível elaborar um esquema simultaneamente justo e eficiente na contenção de gastos (Reiners 1988; Ulrich, 1996; Nolan, 1996; Geißler, 1980). Para que o mecanismo de co-pagamento fosse efetivo como forma de condução da demanda (controle da utilização), no sentido de promover a redução do uso em situação de oferta de serviços mantida constante, seria preciso que os valores estipulados fossem tão altos que se tornariam incompatíveis com um seguro social. Nāo seri-

324 Ugá (1997:78) faz uma diferenciação entre estas duas modalidades, denominando a primeira de tickets ou taxas moderadoras e a segunda de co-pagamento. Preferi utilizar, aqui, o termo co-pagamento por corresponder a uma tradução mais literal do termo empregado em alemão e também porque o sistema utilizado é misto: para algumas açōes sāo estipuladas taxas fixas e para outras são definidas porcentagens de participação.

32.5 Por definição, também não são tidos como co-pagamento outros gastos nāo monetários decorrentes da própria utilização de serviços, como, por exemplo, o tempo despendido pelo paciente na procura e utilização do serviço. 
am socialmente suportáveis, pois a garantia da atenção passaria a estar condicionada à capacidade individual de pagamento por parte do paciente (Geißler, 1980; Reiners, 1993a).

O co-pagamento não é adequado pelas iniqüidades que pode gerar. Todavia, segundo argumento econômico, em sistemas de atenção à saúde com base em seguros, potencialmente, poderia ocorrer um 'excesso de demanda' devido ao que é conhecido como risco moral (moral hazard), pois o mercado de seguros falharia em transmitir eficientes sinais de preços para os consumidores. Isto é, o asseguramento garantiria cuidados a custo zero, o que levaria a mudanças no comportamento do consumidor, que estaria disposto a consumir serviços de saúde ao máximo (Donaldson \& Gerard, 1992; Iunes, 1994). ${ }^{326}$

Os efeitos adversos dos pagamentos diretos no nível de eqüidade são amplamente reconhecidos. Estudos realizados pela OECD em diversos países demonstraram, independente das diferentes estruturas institucionais, que o desembolso direto por parte do paciente é a forma de financiamento mais regressiva que existe. Isto é, os mais pobres pagam relativamente mais (Nolan, 1996:93). Os próprios defensores da introdução do co-pagamento reconhecem que a medida afeta diferenciadamente os grupos de renda, prejudicando aqueles menos favorecidos; tanto que, em geral, são introduzidos escalonamentos e os grupos de menor renda são dispensados dos pagamentos.

A instituição do co-pagamento como medida moderadora da utilização parte do pressuposto de que a demanda em saúde é excessiva - ações desnecessárias seriam consumidas por iniciativa do paciente - e é elástica, ou seja, reduz-se com a elevaçāo dos preços.

Todavia, a demanda por ações de saúde é pouco elástica (a elasticidade varia segundo a faixa de renda do usuário em potencial, como assinalado a seguir). Além de ser predominantemente secundária - definida pelo médico e não pelo paciente -, quando primária, é geralmente imperativa. Situações graves demonstram bem esta inelasticidade. Por se tratar de questão de sobrevivência, a demanda não diminui com o aumento de preços, alocando o demandante o máximo de recursos financeiro que tiver disponível ou disponibilizável. Mas quando há insuficiência da renda, a demanda torna-se elástica. E o que é pior, quanto mais baixa a renda, maior a elasticidade da demanda por serviços de saúde. Para os grupos de baixa renda, a demanda é elástica em relação aos preços

326 Esta acepção é difundida por defensores da introduçāo desta medida, entretanto, é limitado, pois envolve novamente alguns dos pressupostos do mercado ideal: o perfeito conhecimento por parte do consumidor; a desconsideração de que o consumo de ações de saúde envolve outros gastos para o consumidor, como o de tempo; os preços não dependem da ação dos consumidores, mas são negociados com os prestadores, em geral, por um terceiro. Além disso, o mercado falha também em transmitir responsabilidades de custos para os prestadores de cuidados de saúde (Donaldson \& Gerard, 1992:33). 
e o patamar da impossibilidade absoluta é rapidamente atingido, o que significa dizer que pacientes necessitados ficarão sem a assistência devida. ${ }^{327}$

Por um lado, a elasticidade da demanda para grupos de menor renda demonstra que um sistema de co-pagamento é incompatível com a idéia de ser de modo concomitante socialmente justo e promover a diminuição de gastos. Por outro lado, em termos lógicos, o escalonamento de valores conforme a renda com o objetivo de contrapor-se a esta tendência, se completamente efetivo, eliminaria o desejado efeito de contenção (Reiners, 1988; Pfaff, Busch \& Rindsfüsser, 1994). Assim, a introdução do co-pagamento, em lugar de racionalizar o comportamento dos usuários, mais provavelmente contribui para conter a demanda necessária, resultando em subatenção para determinados grupos, do que aquela supérflua, referente à sobreutilização (OECD, 1995b).

A instituição do co-pagamento pode alterar a demanda, ${ }^{328}$ porém, afeta os grupos sociais de forma diferenciada. Experimento realizado nos EUA mostra que o número de contatos primários com o médico decresce com a elevação do valor do co-pagamento (Manning et al. apud Wasem, 1998). Quando o contato ocorre, entretanto, os gastos não são diferenciados entre pacientes com co-pagamento alto e baixo. Neste estudo, não foram identificadas repercussões negativas no estado de saúde de segurados 'médios'. Todavia, em outro estudo, no que diz respeito a níveis de pressāo arterial, acuidade visual e cáries, observou-se que uma cobertura total melhoraria o estado de saúde dos segurados $20 \%$ mais pobres (Keeler apud Schmidt \& Malin, 1996). Além disso, nota-se diminuição de gastos (redução da utilização) apenas entre grupos de segurados com gastos mais baixos (Schmidt \& Malin, 1996). Em síntese, o co-pagamento tein efeito de condução da demanda no sentido de reduzi-la apenas entre os mais pobres, o que não é defensável em termos médicos (Rosenbrock, 1997).

A participação financeira direta dos segurados no ato da utilização nāo é desvantagem apenas para segurados de menor renda, o é também para idosos e pacientes crônicos. O co-pagamento incide de modo mais intenso sobre o grupo de pessoas mais idosas, em particular o segmento dos aposentados, cuja renda é, em geral, também mais baixa. Na Alemanha, enquanto a participação financeira direta anual de pacientes entre 25 e 30 anos fica, em média, em 25 marcos, pacientes entre 70 e 75 anos de idade precisam pagar, em média, 143 marcos, considera-

327 Estudos realizados no Canadá e EUA demonstraram que a reduçāo de contatos é maior nos grupos de mais baixa renda. Especialmente prejudicadas foram as crianças de grupos de baixa renda, para as quais a participação financeira reduziu os contatos em 40\% (OECD, 1995a:55). Na Alemanha, todas as crianças até 18 anos são dispensadas de co-pagamento.

328 Participaçōes modestas dos usuários não influenciam a utilização, mas taxas de co-pagamento substanciais são acompanhadas de número mais baixo de consultas habitante/ano (OECD, 1994:41). Assim, também as experiências africanas são elucidativas das importantes alterações na demanda com o aumento e diminuição da participação financeira direta dos usuários; especialmente aqueles com mais baixas rendas (Ugá, 1997). 
das as diversas modalidades de co-pagamento. $\mathrm{O}$ co-pagamento representa vantagem relativa para os mais jovens, especialmente homens jovens, pois o comprometimento da renda, além de aumentar com a idade, é maior para as mulheres contribuintes do que para os homens, em todas as faixas etárias. ${ }^{329}$

Como a maioria dos gastos está associada a doenças de longa duração, o copagamento concentra-se em certos grupos que correspondern a uma fração pequena dos segurados. Na Alemanha, estima-se que $25 \%$ dos segurados sejam responsáveis por $75 \%$ a $90 \%$ das despesas do Seguro Social de Doença (Schmidt \& Malin, 1996; Pfaff \& Busch, 1997). ${ }^{330}$ A utilização dos serviços de saúde é, por conseguinte, extremamente mal distribuída. Ou seja, grande parte dos gastos em saúde é produzida por pessoas doentes que não poderiam e nem deveriam abdicar de sua atenção. A contenção de custos produzida pelo co-pagamento atingiria assim um grupo de pessoas especialmente necessitado de proteção: idosos e doentes severos (Reiners, 1988 e 1993; Pfaff \& Busch, 1997; Pfaff, Busch \& Rindsfüßer, 1994). Além disso, o estado de saúde e o risco de adoecer - e, por sua vez, a necessidade de cuidados de saúde - estāo fortemente relacionados à renda (Mielck, 1994). ${ }^{331}$ Desse modo, reduz-se a redistribuição ao interior do sistema, corroendo a solidariedade.

Em síntese, dadas as características da demanda em saúde - necessidades em saúde independentes dos preços dos serviços e elasticidade relativa, diferenciada de acordo com a renda -, as medidas de co-pagamento provocam impacto negativo de forma mais acentuada nos grupos de menor renda e os grupos que mais necessitam de atenção, seja em intensidade ou freqüência, sāo os que mais pagam: idosos, doentes crônicos e pacientes severos.

O co-pagamento, portanto, atinge principalmente os mais necessitados de atenção e é uma forma de privatização parcial do risco de adoecer, pois é desembolso direto no ato da utilização. Ocorre, assim, deslocamento de gastos do sistema de seguro social para os domicílios privados. Pode-se assim questionar seus efeitos de aumento de eliciência, pois, se os gastos são transferidos, significa que não ocorreu de fato contenção de gastos (OECD, 1995b; Pfaff \& Busch 1997).

O problema principal com a introdução do co-pagamento - é bom ainda lembrar - é o mesmo daquele de qualquer medida de 'racionalização do comportamento da demanda'. Aplicam-se no paciente medidas destinadas a conter custos,

329 A estimativa da renda comprometida, em 1993, para mulheres variou entre $0,38 \%$ - para o grupo etário de 18 a 24 anos - e 1,42\%. Este máximo foi atingido pelas mulheres de 60 a 64 e 65 a 74 anos. Para os homens, foi de $0,22 \%$ da renda anual no grupo de 18 a 24 anos e de $1,35 \%$ da renda no grupo de 65 a 74 anos (Pfaff, Busch \& Rindsfüsser, 1994).

330 Segundo outra estimativa, $1 \%$ dos segurados produz $38 \%$ dos gastos hospitalares e $39 \%$ dos gastos coll próteses dentárias (Berg apud Reiners, 1988).

331 Para una visão de pesquisa sobre morbidade e desigualdades sociais na Alemanha vide Mielck (1994). Outro estudo interessante analisa a diferença de expectativa de vida conforme a adscrição às Caixas, o que, por sua vez, está relacionado com a renda (Dinkel \& Görtler, 1994). 
quando o aumento de custos é produzido principalmente por fatores relativos à oferta, da qual os pacientes têm conhecimento e influência bastante limitados (Geißler, 1980; Reiners, 1993).

No GKV, reconhecem-se os efeitos adversos dos pagamentos diretos sobre a eqüidade e o peso diferenciado sobre grupos populacionais, sendo estipuladas regras para minorar estes efeitos. O sistema de compensação para garantir maior aceitabilidade e 'suportabilidade social' do co-pagamento existente na Alemanha pode ser julgado abrangente. Famílias de menor renda, crianças e menores de 18 anos são dispensados do co-pagamento. ${ }^{332} \mathrm{O}$ limite de comprometimento da renda anual com pagamentos diretos pelos pacientes é estipulado em $2 \%$ para todas as famílias e para doentes crônicos em $1 \%{ }^{333}$ Atualmente estão dispensadas de copagamento 21,4 milhōes de pessoas, entre estas, em torno de 12 milhōes de crianças, correspondendo a cerca de $30 \%$ dos segurados. Na Região Oriental, como a renda é mais baixa, mesmo com a definição de valores monetários diferenciados, a proporção de segurados dispensados de co-pagamento é maior.

Além da diminuição direta dos gastos ou aumento da receita, outro argumento defendido para a introdução de co-pagamento nos serviços de saúde e para a restituição de parcela de contribuição refere-se ao desenvolvimento de maior consciência de custos por parte dos segurados e ao aumento da 'própria responsabilidade'. É neste sentido que a elevação dos valores de co-pagamento foi empregada como medida coercitiva no caso de majoração das taxas de contribuição. Esta elevação seria o elemento sinalizador de preços para a demanda - os segurados fazer a escolha de Caixa/seguradora.

Entre os segurados nâo há consenso a respeito dos mecanismos de copagamento. Em pesquisa qualitativa efetuada por Ulrich, Wemken \& Walter (1994), três posições estiveram representadas. Uma parte dos entrevistados desaprova o co-pagamento por atentar contra o princípio de solidariedade. Outros consideram-no instrumento de condução do sistema, pois haveria abusos, em particular no uso de medicamentos, o que seria uma atitude não solidária. Um terceiro grupo julga a medida positiva, mas é contra seu uso indiscriminado, em especial no que se refere às internaçōes hospitalares. $\mathrm{O}$ abuso na utilização, neste caso, seria improvável, pois os pacientes não têm influência na definição da necessidade de internação (Ulrich, Wemken \& Walter, 1994).

332 As cláusulas sociais definem liberação total do co-pagamento para segurados cuja renda familiar não ultrapassa $40 \%$ da renda média do conjunto dos segurados (beneficiários da assistência social estão automaticamente incluídos nesta cláusula).

333 Para ter direito a estas liberações parciais, os segurados devem pagar os valores de copagamento, comprovar que ultrapassam o limite de renda anual e então solicitar restituiç̃ô. Para a atenção hospitalar, o limite é determinado em 14 dias de internação, sendo definidas taxas diárias. 
Na Alemanha, o co-pagamento foi medida de contenção reiterada. Estabelecidas em 1977, as regras de co-pagamento, inicialmente apenas para medicamentos e próteses (Pfaff, Busch \& Rindfüsser, 1994), foram modificadas diversas vezes na última década, tendo sido gradualmente ampliados tanto seus valores como os itens incluídos. No Quadro 10 apresentam-se os setores de atenção nos quais incide co-pagamento e suas alteraçōes no final da década de 90 . $\mathrm{O}$ setor mais afetado foi a assistência farmacêutica. Os valores neste setor foram considerados excessivos pela coalizão social-democratas/verdes, que os reduziu.

Quadro 10 -Modalidades de co-pagamento no GKV e valores - 1996, 1997, 1999

\begin{tabular}{|c|c|c|c|}
\hline Modalidade de co-pagamet & 1996 & 1997 & 1999 \\
\hline Medicamentos* & $3,5,7 \mathrm{DM}$ & $9,11,13 \mathrm{DM}$ & $8,9,11 \mathrm{DM}$ \\
\hline Dia internação** & $12 \mathrm{DM}$ & $17 \mathrm{DM}$ & $17 \mathrm{DM}$ \\
\hline \multicolumn{4}{|l|}{ hospitalar - Ocidental } \\
\hline Dia internação & $9 \mathrm{DM}$ & 14. DM & 14. DM \\
\hline \multicolumn{4}{|l|}{ hospitalar - Oriental } \\
\hline Outros métodos & $10 \%$ & $15 \%$ & $15 \%$ \\
\hline \multicolumn{4}{|l|}{ tcrapĉuticos*** } \\
\hline Custos de viagem & $20 \mathrm{DM}$ & $25 \mathrm{DM}$ & $25 \mathrm{DM}$ \\
\hline Próteses dentárias & cntre 40 e $50 \%$ & entre 45 c $55 \%$ & entre 45 e $55 \%$ \\
\hline Próteses dentárias & cntre 40 e $50 \%$ & $100 \%$ & entre 45 e $55 \%$ \\
\hline \multicolumn{4}{|l|}{ nascidos pós 1978} \\
\hline Dia de internação & $12 \mathrm{DM}$ & $25 \mathrm{DM}$ & $25 \mathrm{DM}$ \\
\hline Kur - Ocidental & & : & \\
\hline Dia de internação & $9 \mathrm{DM}$ & $20 \mathrm{DM}$ & $20 \mathrm{DM}$ \\
\hline \multicolumn{4}{|l|}{ Kur-Oriental } \\
\hline Alguns meios de ajuda**** & não & $20 \%$ & $20 \%$ \\
\hline
\end{tabular}

*De acordo com o volume da embalagem: pequeno, médio, grande. **A participação financeira dos pacientes nas internações hospitalares ć limitado a 14 dias ao ano. ****Por exemplo, massagens, ginástica, fonoterapia. ****Bandagens, meias de compressāo, palmilhas.

Pode-se afirmar que o co-pagamento na Alemanha é utilizado mais como fonte de receitas para o sistema do que como mecanismo de controle da utilização. Por um lado, as majoraçôes do co-pagamento visam a cobrir déficits financeiros existentes. Este objetivo foi diversas vezes expresso. Os aumentos estipulados nas 
Leis de Reordenação do GKV foram calculados de modo a cobrir o déficit existente (BMG, 1998c). Por outro lado, o co-pagamento incide principalmente na demanda secundária: prescriçōes e solicitações médicas. ${ }^{33.4}$

Não há co-pagamento para a demanda ambulatorial primária. Embora uma das estratégias de contenção tenha sido a privatização parcial dos gastos com a ampliaçāo das taxas de co-pagamento, não foram introduzidas taxas de participação dos usuários para atenção ambulatorial, setor da atenção onde potencialmente reduziria a demanda por ser este o único em que o segurado pode decidir primariamente a utilização, o que deixa transparecer o poder de influência da corporação médica na Alemanha e a política governamental de clientela.

O desvio dos gastos do financiamento solidário do Seguro Social de Doença para os domicílios privados produzido pela maior participação financeira direta dos segurados afeta a paridade de financiamento. Entretanto, embora o deslocamento de gastos para os segurados tenha sido expressivo em virtude do maior volume de recursos em jogo, a paridade do financiamento do sistema foi pouco afetada imediatamente. Em 1996, segundo estimativas governamentais, 48,1\% de receitas de contribuição do GKV corresponderam à parcela dos empregadores que deveria, segundo o princípio da paridade, ser de 50\% (Bundesregierung, 1997).

Contudo, em comparação internacional, a participação financeira direta dos usuários na Alemanha não é elevada. Segundo estimativas divulgadas pela OECD (1997), a participação financeira direta dos usuários de serviços de saúde na Alemanha (o que é distinto de considerar-se a proporção dos gastos do GKV) em relaçāo ao conjunto das áreas de atenção (9\%) é das mais baixas entre aqueles países, ficando atrás apenas do Reino Unido (7\%). ${ }^{335}$

Na maioria dos países da OECD, observa-se tendência a leve aumento da participação direta dos usuários nas despesas com saúde entre 1980 e 1995 . Todavia, na maioria dos países, o acréscimo da participação foi inferior a cinco pontos percentuais, sinalizando a baixa magnitude em que esta forma de privatização dos riscos de adoecer vem ocorrendo em nível internacional. A privatização não está dada e nem é inevitável. Embora o discurso conservador tenha se espraiado, até o momento não tem sido implementada como apregoada.

Em resumo, co-pagamento é mecanismo inoportuno para a condução do sistema por estar centrado na demanda, tanto porque o aumento dos gastos decorre predominantemente de problemas da oferta - nos quais os pacientes pouco podem influenciar - como porque obriga a demanda a comportamentos inade-

334 No GKV, todas as outras açōes médico-sanitárias - com exceção do trabalho das parteiras e do atendimento psicoterápico - são demandas secundárias.

335 Isso ocorre principalmente pela inexistência de co-pagamento no setor médico ambulatorial do GKV. Nestas estimativas, a participação financeira na assistência farmacêutica no caso de medicamentos, porém, seria maior do que $50 \%$, situando-se em posição média em termos de comparação internacional. 
quados, acentuando iniqüidades no acesso e utilização. Mais provavelmente, pode resultar em subatenção para grupos de menor renda, ao gerar impacto negativo de forma mais acentuada nestes grupos, do que conter a suposta demanda desnecessária ou excessiva. É mais desvantajoso para mulheres, pessoas idosas, pacientes crônicos e severos, corroendo a solidariedade.

Por ser desembolso direto no ato da utilização, o co-pagamento atinge especialmente os mais necessitados de atenção, podendo ser considerado como uma forma de privatizaçāo parcial do risco de adoecer. Medidas de co-pagamento objetivam deslocar gastos do financiamento coletivo/público para os domicílios privados. Deste modo, os empresários são parcialmente desonerados e a paridade de financiamento é afetada.

O sistema de compensações, introduzido para contrapor-se parcialmente aos efeitos indesejados, define limites da privatização dos gastos em saúde, mas não interfere no deslocamento de gastos para os domicílios privados dos pacientes. Este fere a paridade do financiamento e afeta o princípio da solidariedade no que concerne às transferências entre doentes e sadios.

\section{Seleção de piscos: novas opções para contratos com os segurados}

Outras formas de contratos com segurados, nas quais se definem o estabelecimento de proporçōes de restituição, como franquias e prêmios pela nāo utilização, podem também ser classificadas como mecanismos de co-pagamento (Geißler, 1980). Estas medidas têm repercussōes similares àquelas discutidas acima para o co-pagamento, além de servirem à seleção de riscos por serem atrativas apenas para segurados melhor remunerados $\mathrm{c}$ que consideram o seu risco como baixo.

\section{Recompensa monetária pela não utilização: bônus}

A restituição de parcela das contribuições em contrapartida à baixa utilização pode ser entendida como forma indireta de co-pagamento, no qual a participação financeira dos usuários está embutida previamente nas taxas de contribuição. Ao não utilizar, o segurado teria direito à parcela que pagou antecipadamente. É de pressupor que este tipo de medida ocasionaria aumento das taxas de contribuições, pois os bônus pagos pelas seguradoras/Caixas terão de ser cobertos por adequaçôes das taxas de contribuição de todos os seus membros.

Como é medida similar ao co-pagamento, apresenta os mesmos problemas que este, acima apontados, incidindo negativamente sobre o princípio da solidariedade. Apenas os relativamente mais saudáveis podem esperar receber o 
bônus e se o valor deste estiver acoplado ao montante das contribuições pagas pelo segurado, os contribuintes de maior renda terão vantagens expressivas. A probabilidade de desfrutar do bônus é mal distribuída, aumenta com a elevação da renda dos segurados e com a idade, assim como o valor monetário do bônus é mais elevado entre os mais jovens (Pfaff \& Busch, 1997). Quem recebe o bônus é significativamente mais jovem, tem menor número de dependentes e a probabilidade de recebimento é maior entre contribuintes homens do que mulheres (Schmidt \& Malin, 1996). Tendencialmente, este mecanismo implica a redução das transferências dos contribuintes melhor remunerados para os de menor renda, assim como dos sadios para os doentes, reduzindo os efeitos de redistribuição.

Este mecanismo tem sido modificado nos seguros privados, estimulandose a reserva de parcela deste bônus para emprego posterior na compensação da idade. Nos seguros privados, uma parcela do bônus é paga monetariamente ao segurado como estímulo financciro e outra serve como bônus para compensar aumentos do prêmio com a idade (SVR, 1994).

É controverso se esta medida pode ou nāo reduzir a utilização e conseqüentemente os gastos. A introdução deste mecanismo no $\mathrm{GKV}$ redundaria em maiores gastos administrativos, além dos gastos com os bônus. Duvida-se que a contenção produzida possa superar estes gastos adicionais (Schmidt \& Malin, 1996; Braun, 1996). A utilização mais racional por parte dos segurados é pouco provável de ser alcançada, pois os segurados não conhecem os custos das ações de saúde e não podem avaliar efeitos monetários de poupança. Supondose que a implementação da 'recompensa' leve a mudanças de comportamento, estas não necessariamente serão positivas. Pode haver a procura tardia da necessária atenção com efeitos danosos à saúde e a conseqüente utilização posterior mais complexa.

Este mecanismo foi considerado promotor da competição, pois o bônus teria maior aceitação entre os segurados do que o co-pagamento, uma vez que, ao contrário deste último, o bônus aparece como recompensa e seria mais eficaz para atrair bons riscos. Os segurados posicionam-se favoravelmente à restituição de uma parcela das contribuiçōes aos segurados que nada ou pouco utilizaram, pois embora o princípio da solidariedade seja aceito e difundido, as representaçōes dos segurados são impregnadas pelo princípio da equivalência constitutiva do modelo de seguro social, segundo o qual os benefícios devem estar relacionados ao mérito. ${ }^{336}$ As mesmas pesquisas, no entanto, fazem duvidar das possíveis mudanças de comportamento na utilizaçāo. A grande maioria dos entrevistados (95\%) afirma que não renunciaria a atendimento médico por este motivo (Schmidt \& Malin, 1996).

336 Cerca de $70 \%$ dos segurados entrevistados concordaram com a afirmativa: "quando o segurado utilizar muito pouco, ou não utilizar, serviços de saúde ele deve receber de volta uma parcela correspondente de sua contribuição" (SVR, 1994:221). 
Em virtude dessas estimativas, poucos efeitos de contenção podem ser esperados da introdução de bônus pela baixa utilização. Mais do que uma forma de racionalização do comportamento da demanda, a medida visaria, portanto, a servir de parâmetro à seleção de riscos e estimular a competição por segurados.

\section{Opção por uma franquia}

A opção por uma franquia (Selbstbehalt), isto é, a renúncia pelo segurado de uma parte da cobertura, é mais um procedimento que pode ser enquadrado entre os estímulos monetários de 'racionalização do comportamento da demanda', significando privatização parcial da cobertura do risco de adoecer. Como deslocamento de gastos, tem as mesmas conseqüências acima apresentadas para o co-pagamento.

Por ser opcional, a assunção de franquia, mais do que deslocar gastos, possibilita a seleção de bons riscos, do mesmo modo que a distribuição do bônus. Apenas segurados que avaliam como baixa a probabilidade de utilizar serviços e que são relativamente melhor remunerados é que poderāo optar pela assunção de franquia. Pessoas doentes ou com salários mais baixos não poderão se questionar quanto à possibilidade de assumir parte dos gastos.

O desconto de taxas de contribuição mais baixas, possibilitado pela assunção de franquia, poderia ser atraente para grupos de segurados de menor renda, porém, os problemas decorrentes desta opção seriam ainda maiores. As pessoas de baixa renda estariam tentadas a contratar seguros com tarifas mais baixas para aumentar seus orçamentos familiares. Contribuiçōes mais baixas sāo incentivo econômico para este grupo, que poderia ignorar seus riscos de utilizaçāo e confiar na manutenção do estado de saúde, mesmo sem ter rastro financeiro suficiente para cobrir possíveis despesas. Neste caso, o necessário atendimento poderia deixar de ser procurado ou retardado, afetando o estado de saúde destes grupos (Gerlinger, Giovanellla \& Michelsen, 1997).

Do mesmo modo que no caso do bônus discutido anteriormente, mais do que estimular a utilização mais parcimoniosa por parte dos segurados, a medida é vantajosa para aqueles segurados que utilizam pouco devido ao seu estado de saúde.

Em resumo, as tarifas opcionais são vantajosas e interessam aos bons riscos - saudáveis, provável baixa utilização e renda mais elevada - e provocam deslocamento de gastos entre os segurados, dos doentes para os mais saudáveis (no sentido inverso de uma redistribuição solidária). Os segurados que optarem por estes mecanismos contribuirão com menos para o fundo solidário, tornando as taxas de contribuição do conjunto restante mais altas, uma vez que os que sobram apresentam riscos mais elevados, correspondendo a maiores despesas. 
Tais mecanismos em seu conjunto penalizam os doentes. Estes pagam contribuições mais elevadas e, ainda, a participação financeira no ato da utilização, da qual não podem prescindir. ${ }^{337}$

\section{Racionalização da Oferta: eficiência via novas relações entre Caixas e prestadores?}

Diversas das medidas implementadas durante a década de 90 podem ser tipificadas como de racionalização da oferta. Entre estas, incluem-se a definição de tetos orçamentários por setores de atenção, as mudanças nos sistemas de pagamento dos setores ambulatorial e hospitalar, as medidas regulatórias da assistência farmacêutica, deslocamento de atividades do setor hospitalar para o ambulatorial, entre outras. Enquanto na terceira etapa a ênfase foi em medidas restritivas da demanda, a Lei da Reforma do GKV 2000 introduziu diversos incentivos à reorganização da oferta de serviços e do modelo assistencial, estimulando: a articulação entre os setores ambulatorial e hospitalar, a constituição do clínico geral como porta de entrada e a conformação de redes integradas de atenção.

As mudanças nos sistemas de pagamento empreendidas, assim como a definição de tetos máximos por setor de atenção, são importantes medidas de 'racionalização da oferta'. A definição de limites de gastos por setor é prática reiterada desde 1978, em particular para o setor ambulatorial. Ao final dos anos 80 , a este modo de contenção foram somadas mudanças nos sistemas de pagamento hospitalar e ambulatorial. No setor hospitalar, pagamentos prospectivos foram introduzidos com a Lei da Estrutura da Saúde a partir de 1993. No setor ambulatorial, o sistema de remuneração médica foi expressivamente modificado com a 2.NOG de 1997, após uma série de alterações parciais, tendo sido criado um misto de pagamentos prospectivos (pagamentos por caso tratado), valoração por unidades de serviço e definição de tetos máximos por consultório, como visto.

Este conjunto de medidas de 'racionalização da oferta', mudanças nos sistemas de pagamento, definição de preços e tetos orçamentários, podem ser consideradas, em sua lógica indutiva, como formas de pagamento prospectivo, trazendo consigo os mesmos problemas que tais métodos. Sistemas de pagamento prospectivo invertem a lógica dos estímulos econômicos para a prestação de servi-

337 Lembrando ainda que todos estes mecanismos significam claras desvantagens para as mulheres contribuintes. Estas, em geral, têm rendimentos mais baixos e probabilidade de utilização mais alta (Zoike, 1997). 
ços. Os pagamentos prospectivos incentivam a redução da atenção dispensada a cada paciente, trazendo consigo o perigo da subassistência, enquanto os sistemas de pagamento por unidades de serviço no setor ambulatorial e por meio de diárias únicas no setor hospitalar, que até então garantiam o pagamento de qualquer serviço produzido, estimulavam uma sobreassistência (Kühn, 1995a).

Alguns autores consideram estas mudanças nos sistemas de pagamento como elemento de competição. A idéia desta forma de pagamento seria o estabelecimento de preços fixos por caso tratado ou procedimento realizado, independente do consumo de recursos envolvidos em cada caso concreto. Orientados pelo lucro, hospitais poderiam passar a selecionar casos mais vantajosos e especializarse em procedimentos mais lucrativos.

Os sistemas de pagamentos prospectivos instituídos para os setores ambulatorial e hospitalar - cada qual com suas especificidades - compreendem uma série de mecanismos que visam a se antepor a estes efeitos indesejados. Esta modalidade de sistemas de pagamento acarreta acompanhamento e rigorosa vigilância da qualidade, de modo a evitar que se faça economia às custas da qualidade da atenção prestada aos pacientes.

\section{Yovas formas de organização da atenção}

Ainda que de forma pouco abrangente, as leis de 1997 facilitaram a diferenciação dos contratos das Caixas com os prestadores mediante a experimentação de novos modelos de organização, financiamento e remuneração, bem como de 'estruturas organizacionais', modelo do médico generalista, (Hausarztmodell), e consultórios em rede (Vernetzen Praxen). Deste modo, inovações da organização da atenção experimentadas até então por algumas Caixas na forma de projetos piloto de baixa cobertura poderiam ser difundidos, com limitações nois, em ambos os casos, os contratos somente poderiam ser negociados com as Associaçōes de Médicos das Caixas e com prazos limitados. Pela Lei da Reforma do GKV 2000, todavia, uma Caixa pode negociar com grupos de médicos credenciados ou hospitais ou com as Associaçōes de Médicos da Caixas (Kven). Assim, o direito de exclusividade destas Associações é quebrado, sendo estimulada a concorrência entre prestadores.

Por meio de formas diferenciadas de contrataçāo de prestadores e mudanças nas formas de organização da atenção, as Caixas deveriam redirecionar sua competição para o campo das modalidades assistenciais, colocando formas inovadoras, menos onerosas e de melhor qualidade à disposição dos segurados e da sua clientela postulante.

As novas formas de organização da atenção foram preconizadas pelos defensores da 'concorrência da oferta'. A inclusão dessas formas organizacionais recomendadas pelas Caixas e pela Central Sindical (DGB) mostra, por um lado, a tentativa, 
embora tênue, de compromisso da coalizão governamental conservadora-liberal com esses atores e, por outro, a mudança de ênfase da política impulsionada pelos socialdemocratas e verdes. Estas medidas, contudo, não são incompatíveis com os propósitos de contenção e competição. Bem o demonstram as experiências de managed care ou 'atenção gerenciada' - as modalidades americanas da relação entre provedores de seguro/financiadores da atenção e prestadores de ações médico-sanitárias.

No modelo sugerido pelas Caixas Locais (Hausarztmodell der AOKen), o segurado escolhe um clínico geral ao qual deve recorrer como primeira alternativa e que passa a coordenar a sua atenção. $O$ médico deve responsabilizar-se pela coordenaçāo de seu tratamento, orientando-o sobre as possibilidades terapêuticas e as ações disponíveis, fazendo os encaminhamentos necessários. Neste modelo, pretende-sc o manejo médico e social do caso. A orientação psicossocial, a prevenção e a reabilitação seriam tarefas a cargo do médico geral e/ou sob sua coordenaçāo, o que melhoraria a qualidade da atenção e evitaria desperdícios e a prestação de serviços desnecessários (Stegmüller, 1996).

O modelo implementado experimentalmente por Caixas de Empresas consultórios em rede com orçamentos combinados (vernetzen Praxen bei kombinierten Budgets) - envolve a criação de centros de atenção integrados com orçamentos combinados por iniciativa dos próprios prestadores: médicos de várias especialidades e outros profissionais de saúde compōem uma rede de atenção e partilham orçamento comum. Diversos critérios para admissão dos médicos no esquema são previstos, tais como: qualificação, conhecimentos em epidemiologia clínica, $\mathrm{cm}$ ações psicossociais, experiência $\mathrm{em}$ trabalho cooperativo, prévia participação em círculos de qualidade. A estrutura organizacional, por sua vez, fundase na transparência, redes internas de computadores, na comunicação entre prestadores, discussão de casos e sistema de segunda opiniāo, e no desenvolvimento de protocolos de condutas e terapêuticos (Richard \& Schönbach, 1996).

Estas novas modalidades de atenção garantiriam oferta coordenada $\mathbf{e}$ abrangente de açōes médicas gerais e espccializadas, métodos terapêuticos e diagnósticos, além de orientação de longa duração para pacientes crônicos e na área de geriatria. A intenção seria incluir, o máximo possível, os gastos com terceiros nòs orçamentos combinados (medicamentos, outros métodos terapêuticos e exames diagnósticos), evitando o deslocamento de gastos para outros setores, como, por exemplo, para encaminhamentos à investigação diagnóstica em regime de internação. Uma atenção integrada contribuiria, ao mesmo tempo, para a melhora da qualidade e da eficiência da atenção prestada. Segundo as Caixas Substitutas, estas formas integradas de atenção facilitariam a introdução de mecanismos para a promoção da qualidade e eficiência, tais como a elaboração de protocolos de condutas para diagnóstico e tratamento de doenças específicas, discussão de casos, solicitação de pareceres, lista positiva de medicamentos etc. (AG-KK, 1994:21). 
A livre escolha a segurados e prestadores é garantida. Ambos podem optar entre as formas de organização da atenção inovadoras e a forma tradicional. Como estímulo à escolha de um dos novos modelos de organização da atenção pelos segurados, as Caixas podem oferecer bônus de adesão na forma de retorno de parcela de suas contribuições (Bundestag, 1999). Além disso, os segurados supostamente viriam a optar por estas modalidades de atenção integrada em virtude das vantagens em termos de qualidade e de coordenação da atenção.

As novas formas de atenção são introduzidas com o propósito de resolução de problemas quanto à expansão excessiva do volume de açōes prestadas e de insuficiente integração ao interior do sistema - tanto dos médicos entre si e com os outros prestadores em seu conjunto como entre o setor ambulatorial e hospitalar - não apenas no que concerne à prestação de serviços, como também ao financiamento dos mesmos (Schönbach, 1997). A falta de integração ao interior do sistema de atenção é um dos problemas reiteradamente diagnosticado, em especial, a não articulação entre setor hospitalar e ambulatorial, mas tocado de modo indireto por diversos procedimentos até então implementados. A criação dos 'consultórios em rede' e do 'modelo do médico generalista' pode vir a tornar-se a mais importante medida no sentido de promover maior integração.

Sistemas integrados de atenção são importantes para dar conta do acompanhamento de pacientes portadores de doenças crônicas, para os quais os sistemas de atençăo à saúde, em geral, estão pouco preparados. Este não é problema apenas do sistema de saúde alemão, mas da atenção médica contemporânea, que, fragmentada pela especializaçāo crescente, não consegue garantir atenção integral e integrada ao paciente. A medicina atual ainda não está preparada para o atendimento de doenças crônicas.

Conquanto o modelo anterior para a atenção de doenças crônicas asilar e de exclusão seja hoje exceçāo, um novo modelo assistencial que dê conta da atenção integral e integrada voltada ao paciente crônico está por ser arquitetado e implementado. Renovar o papel do clínico geral e compor uma equipe de saúde com suas novas e diversas profissões e especialidades médicas, objetivando articular a atenção nos vários níveis de complexidade do sistema são tarefas urgentes. $O$ atendimento das necessidades de saúde de modo integral requer uma cadeia de atenção composta com serviços de promoção e prevençāo, centros de saúde interdisciplinares, agregando as diversas especialidades médicas, instalações para clínica-dia no setor ambulatorial e, ao final, o hospital como centro de atenção complexa.

A abertura legal de alternativas à negociação entre Caixas e prestadores por meio dessas formas de organização da atenção pode contribuir neste sentido. Esta contudo não é tarefa fácil. Este desafio exige a democrática participação de todos os atores, a comunicaçāo e a interação entre os participantes do sistema. $\mathrm{O}$ ambiente competitivo limita as possibilidades das mesmas. O jogo estratégico da competição supõe a anticooperação. 
Semelhantes medidas podem ser consideradas como formas de atenção gerenciada (managed care), pois visam a mudar o comportamento dos prestadores, apresentando elementos similares ao mesmo e, por conseguinte, apontando problemas comuns. Managed care seria um caminho para obtenção de maior racionalidade nas decisōes médicas por meio de medidas de controle da prestação, $\mathrm{e}$ mediante o compartilhamento de responsabilidades financeiras entre prestadores e provedores de seguros. Diversas medidas de controle sầo introduzidas com o objetivo de alterar o comportamento dos prestadores. Nesta concepção, o médico geral, como gatekeeper, auxiliado por pessoal administrativo que năo entra em contato com o paciente, distribuiria os recursos de forma mais eficiente ao cortar açōes dispendiosas, desnecessárias e inefetivas.

Contudo, o resultado de melhor e mais eliciente atenção não está garantido. No caso do managed care americano, um de seus problemas mais importantes é a intervenção de pessoal administrativo do seguro, ao qual o médico está obrigado a recorrer para solicitar autorização concernente ao procedimento fora da rotina e para cada internação. Isto pode interferir na qualidade da atenção, uma vez que o controle passa a ser exercido pela própria seguradora, cujo interesse econômico é reduzir as despesas para manter prêmios baixos e garantir sua parcela no mercado, o que pode resultar em racionamento puro e simples. Além disso, os próprios prestadores passam a assumir medidas internas de controle de custos e de utilização quando os riscos financeiros são compartilhados entre seguradoras e prestadores.

Este tipo de estratégia pressupõe que a participaçāo dos prestadores, médicos e hospitais, nos riscos financeiros seria estímulo adequado para que tivessem, como primeira preocupação, a manutençāo da saúde de seus segurados e, por esse motivo, enfatizariam medidas preventivas e estimulariam a assunção de comportamentos saudáveis por parte de seus pacientes. O clínico assumiria novas tarefas preventivas com o intuito de garantir clientela mais saudável, o que redundaria em menores gastos: ${ }^{\text {338 }}$ Pelo mesmo motivo, pressupõe-se também que os médicos realizariam os cxames estritamente necessários, prescreveriam um mínimo de medicamentos (caso estivessem incluídos na cesta) e encaminhariam a especialistas ou solicitariam internação apenas quando estritamente necessário.

A experiência americana, contudo, tem demonstrado que o estímulo a ações preventivas năo acontece (Schwartz \& Busse, 1994; Schlesinger, 1996). Os resultados dos sistemas de atenção gerenciada americanos são positivos apenas em ter-

338 Nos esquemas comerciais, o interesse não está na prevenção de doenças - redução do sofrimento humano -, mas na prevençăo de gastos, o que leva a duvidar desta possibilidade de mudança na atenção. 
mos microeconômicos - alcançam controlar custos. ${ }^{339} \mathrm{O}$ alcance de maior eficiência, porém, não necessariamente assegura a qualidade da atenção. Os controles sobre os prestadores levam à redução de gastos, mas não se pode inferir que um mínimo de atenção equïivale à atenção de qualidade. No modelo de 'atenção gerenciada' dos seguros privados há risco evidente e grande estímulo a uma subatenção. A delimitação entre o que é estritamente necessário e a atenção supérflua pode ser substituída pelo racionamento puro e simples, prejudicando a qualidade da atenção. Como afirma Ugá (1997:138), "a atenção gerenciada teve impacto positivo sobre a redução dos custos dos tratamentos em saúde, mas estas reduções podem estar se dando em detrimento da qualidade e do acesso".

Foge ao escopo do trabalho uma discussão mais aprofundada a respeito do managed care. $\mathrm{O}$ interesse aqui é alertar para os problemas que esta forma de relação entre seguradoras e prestadores pode implicar, com base na experiência americana e de acordo com os estímulos que introduz. O que não é o mesmo que afirmar estes resultados no caso da Alemanha, onde o aparato político-institucional é bem diverso do americano. As Caixas são públicas e administradas paritariamente por trabalhadores e empregadores, há tradição de solidariedade, o sistema é muito regulado e os médicos são organizados de forma unitária em associações regionais, só para citar aspectos que podem tornar proposiçōes similares substancialmente distintas quanto aos resultados de sua implementaçăo.

Defensores da introdução de mecanismos de managed care na Alemanha ponderam que este deveria ser 'domesticado'. Na experiência alemã, os aspectos da informação são particularmente enfatizados, seja pelo lado dos pacientes, por meio de serviços de aconselhamento e orientação e ações de coordenação da atenção para os segurados, em especial, os doentes crônicos, seja pelo lado dos prestadores, os médicos credenciados, que serão melhor informados a respeito da infra-estrutura local e seu comportamento em termos de prescriçōes e encaminhamentos. Afora isso, tanto prestadores como produtores (indústria médico-farmacêutica), bem como os distribuidores (farmácias), deveriam ser igualmente integrados a um gerenciamento abrangente da saúde. Hospitais seriam estimulados a escolher alternativas mais baratas e melhorar a qualidade, e a indústria farmacêutica participaria de projetos de gerenciamento de doenças crônicas (Knieps, 1996).

O debate em torno das novas formas organizacionais mostra também como medidas racionalizadoras podem incorrer em uma diversidade de interpretaçōes. As novas formas organizacionais da atenção propostas podem ser vistas principal-

339 No afă de eficiência, por vezes, autores extrapolam conclusōes de garantia de qualidade a partir do alcance de redução de gastos hospitalares e da renda de médicos de algumas especialidades - resultados de eficiência -, afirmando, sem delongas, que a qualidade está, ao mesmo tempo, garantida. Este é o caso do debate no Brasil interno ao setor de saúde suplementar. Veja, por exemplo, Nicz (1998). O autor faz descriçāo do managed care e HMOs, enfatizando os resultados de eficiência. 
mente como um modo de contenção, dado o exemplo da atenção administrada nos EUA, ou concernentes às necessidades de maior articulação entre os prestadores para proporcionar atenção integral: uma nova abordagem na atenção de doentes crônicos. Estes resultados dependerăo dos modo de regulação e de especificidades do processo de implementação.

É difícil avaliar em que extensão as novas formas organizacionais definidas na lei - clínico geral e consultórios em rede - virão a ser implementadas, pois dependem tanto da adesão voluntária dos prestadores como dos segurados. Se implementadas e comprovadas as suas potencialidades, seja de diminuir custos, seja de melhorar a qualidade da atenção, pode-se pressupor que estas novas formas de organização da atenção, mais do que utilizadas para a competição entre as Caixas, venham a ser gradualmente assumidas por todas. Caso alguma Caixa alcance sucesso com alguma forma organizacional, outras poderão vir a copiá-la ou contratar o mesmo grupo de prestadores. ${ }^{340} \mathrm{~A}$ ampliação das possibilidades de oferta de formas de atençāo diferenciadas pode resultar na reorganização parcial do modelo assistencial e levar a nova divisão de trabalho no setor ambulatorial, reordenando-o.

Na perspectiva de novos modelos de atenção, o discurso da eficiência, para além dos cortes que em geral acarreta, pode, deste modo, contribuir para colocar em questão o padrão moderno de resposta social ao problema das doenças e fazer transparecer os limites da atenção médica individual e curativa. A promoçăo e a prevenção vêm sendo reatualizadas e a organização do sistema de atenção à saúde readequada com o intuito da contenção, o que pode ser uma brecha para ampliar os questionamentos sobre limitaçōes da biomedicina no enfrentamento do sofrimento humano.

$\mathrm{Na}$ discussão e constituição de novas formas de organização da atenção, a inadequabilidade na abordagem de doenças crônicas, a baixa garantia de resultados positivos de grande número de intervençōes - terapias cujos resultados positivos não ultrapassam os produzidos com efeitos placebo, intervençōes que aprofundam o sofrimento e aceleram a morte, levando a uma iatrogenia velada -, a (re)descoberta das potencialidades individuais na superação das doenças (coping, Krankheitsbewältigung) e a importância do apoio social (social support) no desenvolvimento de estratégias individuais $^{341}$ são questōes que podem ser melhor exploradas, contribuindo para a construçāo de atenção integral à saúde, no sentido de englobar não apenas a promoção, prevenção, tratamento e reabilitação, mas também considerando e enfrentando aspectos sociais, psíquicos e espirituais do adoecer humano.

340 Assim ocorreu, por exemplo, em experiência com 'consultórios em rede' da Associaçăo das Caixas de Empresas em aliança com a Caixa Substituta para Técnicos (Schönbach, 1997).

341 A pergunta sobre como explicar diferenças na evolução de pacientes (freqüência de recidivas e tempo de sobrevida) acometidos da mesma enfermidade e submetidos a idêntico tratamento suscita interesse crescente pelas formas individuais de resposta às doenças crônicas. Os comportamentos para superação do problema pelos atingidos têm sido concebidos como mediadores do desenrolar da enfermidade (Pöhlmann, 1992). 
Assim como o alcance de vida digna está na superação da miséria e na redução das desigualdades, o enfrentamento da doença e uma morte digna dependem de cuidados integrais e de adequados apoios psicossociais para todos. Uma atenção integral, neste sentido, como resposta social, pode contribuir para morte digna quando inevitável, e para melhor qualidade dos cuidados, quando a recupcração for possível.

A reatualização da promoção e prevenção da saúde possibilita a abertura de discussão a respeito da necessidade de medidas de promoção, no sentido de deslocar o surgimento de doenças crônicas para idades cada vez mais avançadas. Em oposição à tese de que os anos ganhos em expectativa de vida em idades avançadas seriam de qualidade precária em razão de padecimentos e limitaçōes, há evidências de que a erupção das doenças crônicas pode ser retardada (Fries, 1984; Kühn, 1995c) e que a qualidade de vida na velhice pode ser melhorada (House, Kessler \& Herzog, 1990). As barreiras para alcançar condições salutogênicas (promotoras da saúde) são de natureza política e social, e não biológica (Kühn, 1995c).

Quando as restriçōes crônicas e a evoluçāo da expectativa de vida são analisadas de forma diferenciada, conforme o status socioeconômico, conhece-se que a duraçāo e a qualidade de vida dos seres humanos não está determinada por destino biológico ou demográfico. A tese da piora da qualidade de vida nos anos prolongados às custas do progresso médico vale apenas para as populaçōes pertencentes aos estratos socioeconômicos inferiores. Deslocar o aparecimento de doenças e restriçōes para idades mais avançadas é utopia realizável, pois já conquistada pelos setores populacionais de padrāo socioeconômico mais elevado, como demonstram estudos epidemiológicos que analisam a conexão entre idade, estado de saúde c status sociocconômico (House, Kessler \& Herzog, 1990).

$\mathrm{O}$ reconhecimento dessas desigualdades implica direcionar as políticas de saúde no sentido da promoção da saúde de forma coletiva e (não apenas de mudanças nos estilos de vida individuais) e do alcance de maior eqüidade em resultados de saúde por meio de políticas intersetoriais. Estas novas políticas envolvem redistribuição e reatualização dos objetivos de justiça social.

\section{Contenção e Constelação Dolítica: atores e processos políticos}

Ainda que esta análise tenha sido centrada nas medidas aprovadas, a observação do processo de reformas permite tecer consideraçōes mais gerais sobre os processos políticos e a participação dos atores. Mudanças legais no Seguro Social de Doença alcmão têm sido tradicionalmente de difícil aprovaçāo. Em geral, o 
que é aprovado ao final do processo corresponde à pequena parcela do projeto original proposto pelo ministério responsável, ${ }^{32}$ o que tem sido imputado à grande quantidade de atores sociais interessados que têm algo a perder ou a ganhar com a reforma (Behaghel, 1994; BMAS, 1994).

No processo recente de reformas, os atores sociais e seus interesses específicos se fazem presentes e, ao mesmo tempo, a intervençāo estatal direciona os resultados. Sem pretender dar conta da complexidade dos processos político-sociais, na observação do processo de reformas da década de 90 , podem ser destacadas: direcionalidade dada pela coalizão governamental conservadora-liberal no sentido de contenção e na escolha das opçôes; importância das constelaçōes políticas na produção de mudanças; influência dos diversos atores e interesses setoriais de forma subordinada, mas, ao mesmo tempo, como barreira de contençāo da contençāo; redefinição dos âmbitos de atuação e de graus de liberdade de ação das estruturas corporativas; além da contemplação de interesses de clientelas políticas específicas.

A coalizão conservadora-liberal imprimiu direcionalidade às políticas de saúde no sentido da privatização parcial dos riscos com o propósito de reduzir os custos sociais do trabalho, subordinando a política de saúde a uma política econômica orientada a garantir a posição do capital alemão na competição internacional. Na terceira etapa, inegavelmente interesses dominantes impuseram limites à atuação dos atores corporativos e definiram a direcionalidade dos processos.

A política social foi submetida aos interesses da política econômica. A coalizāo conservadora-liberal subordinou a política social aos propósitos de diminuição dos gastos sociais do trabalho como fator de melhoramento da posição do capital alemão na concorrência internacional, tal como aos objetivos de ajuste da economia alemã para garantir estabilidade monetária e preencher os critérios de Maastricht (baixa taxa de inflação, déficit público menor que $3 \%$ do PIB). A redução dos custos do trabalho supostamente produziria vantagens para a posiçăo da Alemanha na competição internacional (Standort Deutschland) (fator/custo Alemanha) no sentido de atrair capitais e evitar que o capital alemāo busque novas regiões mais favoráveis para investimentos. ${ }^{343}$

342 Até 1991, Ministério do Trabalho e da Ordem Social, ao qual cabia a vigilância do GKV. A partir de então esta competência foi transferida ao Ministério da Saúde.

34 Nesta retórica é surpreendente a similaridade de discursos no Brasil e na Alemanha, que têm situações díspares de mercado de trabalho e de custos do trabalho (para o capitalista, os custos totais do trabalho é que são importantes e não apenas os custos sociais do trabalho, pois the é indilerente gastar com contribuiçōes sociais ou salários diretos). Tal argumentação elucida a força ideológica do discurso. Para nós, se o preço do trabalho fosse fator determinante para o deslocamento de capitais, não haveria mais desemprego ou mercado informal de trabalho no Brasil. Capitais produtivos em grande escala teriam sido atraídos para cá. Pelo lado da Alemanha, é difícil falar em posição ruim quanto à concorrência internacional, já que ocupa o segundo lugar em volume de exportações: mais do que o Japão, ficando atrás dos EUA. Esta comparação esclarece que a dominância deste tipo de discurso econômico nāo é exigência da natureza das coisas, nem econômicas, nem naturais, mas de escolha política. 


\section{Constelações políticas e interesses específicos}

O acompanhamento do processo de discussão e aprovação da terceira etapa da saúde, assim como das duas etapas anteriores da 'reforma', evidenciou os inúmeros interesses envolvidos e permitiu observar de que modo a conformação de diferentes constelações políticas produz distintos resultados.

Um cotejo entre os conteúdos da Lei da Estrutura da Saúde (GSG) e das Leis de Reordenamento (NOG) mostra como a constituição de diferentes constelações de atores e interesses em cada conjuntura provoca impacto de forma distinta nos princípios constitutivos do GKV. Ao mesmo tempo, revela que reformulaçōes mais profundas exigem a formação de amplos consensos, como foi o caso das mudanças de caráter mais estrutural introduzidas pela Lei da Estrutura da Saúde (GSG), de 1992. A GSG foi elaborada a partir de acordos entre a democracia cristã e o partido social-democrata, sem a participação dos liberais (do FDP, que integra a coalizão governamental). Esta grande coalizão possibilitou importante intervenção na organização do GKV: a maior concorrência entre as Caixas, aberta com a ampliação da liberdade de escolha pelos segurados e a criação do importante mecanismo de compensação financeira entre elas - compensação da estrutura de riscos - como forma de prescrvar o princípio de solidariedade em situação de competição.

O consenso entre conservadores e social-democratas possibilitou também a intervenção em interesses setoriais. O consenso político mais ampliado possibilitou que controles sobre os prestadores fossem aprovados e interesses dos produtores atingidos, como os dos médicos com a imposição de sanções caso ultrapassassem os orçamentos para medicamentos, e os dos produtores, com a aprovaçāo de lista positiva de medicamentos: a seleção de medicamentos de eficácia comprovada. No setor hospitalar, permitiu a mudança no sistema de pagamento e do financiamento. ${ }^{3 \cdot 4} \mathrm{Um}$ modelo que incentivava a maximizaçāo em termos da expansão do volume de serviços produzidos, o pagamento de diárias uniformes, calculadas de modo a cobrir totalmente os gastos do hospital, foi substituído por modelo misto, que estimula a redução de emprego de recursos na prestação de cuidados: sistema de remuneração por casos/procedimentos. No interregno entre as duas leis, contudo, a base de apoio que aprovou a GSG se desfez, e os mais importantes controles não se efetuaram. Por pressão direta da indústria farmacêutica, a lista positiva não foi elaborada e as sanções sobre os médicos, aplicadas apcnas em parte.

O propósito das mudanças introduzidas com a Lei da Estrutura da Saúde, no entanto, foi a organização dos pressupostos, a ampliaçāo da liberdade de escolha das Caixas e a compensação da estrutura de riscos, para viabilizar a competição entre as Caixas. As concepçōcs para a competição entre conservadores e social-

34 Por conta da negociação com e interesse de governos estaduais. 
democratas eram diferenciadas e, na terceira etapa, a coalizão governamental concretizou a competiçāo ao interior do sistema segundo seus propósitos de privatizaçāo da demanda.

As Leis de Reordenação de 1997, por sua vez, foram elaboradas e aprovadas pela coalizão governamental sem a participação dos social-democratas, resultando em importante intervenção na autonomia das Caixas com a imposição de drásticas sançōes no caso de aumentos de taxas de contribuição e na privatizaçāo parcial do risco de adoecer por meio de forte majoração do co-pagamento.

$\mathrm{Na}$ terceira etapa, embora a coalizão governamental ao final tenha dado a direcionalidade do processo, a evolução dos projetos governamentais durante os percursos de discussão e votação mostra a influência, de modo concomitante, dos diversos atores sociais na formulação da política de saúde. Estas modificações evidenciam a miríade de interesses imbricados no setor. Modificaçōes foram introduzidas por pressão não apenas das grandes organizações de interesses trabalhadores, empresários, produtores de insumos e equipamentos -, mas também dos diversos tipos de prestadores, grupos de segurados e governos locais.

A influência dos diversos atores nāo se faz presente de forma homogênea ao longo do processo, oscilando quanto aos objetivos contemplados. Por um lado, devido à pressão de diversos atores com interesses setoriais diretos, as medidas aprovadas, no que concerne a cortes e diversificação do catálogo de açōes e serviços, são menos drásticas do que o proposto de início pelo Conselho de Experts da Ação Concertada em Saúde (SVR). Por outro lado, quando se comparam a primeira e a segunda propostas da coalizão governamental - uma enviada ao parlamento em 1995/1996 e a outra, em 1997. Observa-se incremento da ênfase conservadora-liberal de 'privatização da demanda', em especial, por meio da forte majoração dos valores de co-pagamento e da introdução de mecanismos drásticos, coagindo as Caixas a perseguir o objetivo de estabilização das taxas de contribuição.

Já em relaçāo ao pacote de economia (Sparpaket), ainda que sob intensos protestos, a coalizāo governamental faz valer a maioria parlamentar, mantendo sua posiçāo e introduzindo poucas alterações. A influência dos trabalhadores organizados vai se exercer então em scu campo de negociação, os acordos coletivos, onde os trabalhadores, em sua maioria, conseguiram garantir os direitos anteriores em contrapartida à concessão de pequenas compensações. ${ }^{345}$

No processo de discussão da lei aprovada, diversos outros grupos se manifestaram, além das organizaçōes clássicas de representação do capital e do trabalho, federação de empresários (BDA) e Central Sindical (DGB), cujos interesses estāo inscritos na organização corporativa e autônoma do sistema, e dos principais prestadores setoriais que fizeram propostas setoriais específicas, buscando influenciar a política, representando os interesses dos contribuintes e de seus associados.

$34.5 \mathrm{O}$ que mostra que a sociedade do trabalho, e suas formas clássicas de organizaçāo, continua viva. 
A alteração do projeto de lei governamental, 2.NOG, retirando-se a proposta de separação do catálogo em obrigatório e outro opcional, composto por diversas ações a serem definidas nos estatutos de cada Caixa, deixou transparecer outros interesses. Manifestaram-se diversos grupos com interesses específicos nas ações passíveis de corte, mostrando a amplitude da constelação de interesses envolvidos: econômicos (prestadores de serviços, donos e trabalhadores das clínicas de restabelecimento, governantes dos balneários), profissionais da área (fonoaudiólogos, terapeutas em geral), grupos de pacientes, associações de portadores de deficiências, familiares etc. Este caso foi um claro exemplo dos múltiplos componentes da base de sustentação dos welfare states pela variedade de interesses envolvidos e pela transparência com que se manifestaram como fonte de resistência à introdução de cortes em programas sociais.

Além da recusa mais difusa da introdução de cortes expressa pela mídia e das manifestações dos principais atores setoriais, grupos especílicos não só de prestadores como também de pacientes afetados posicionaram-se contra cortes de benefícios/ações específicas. Colocaram-se em defesa da continuidade das internações de caráter preventivo no catálogo obrigatório os prestadores públicos e privados, os trabalhadores empregados neste setor, por meio de seus sindicatos específicos, os governos de municípios cujas economias são dependentes destes serviços e os respectivos estados. ${ }^{3.46}$ Contra os cortes em outros métodos terapêuticos, pacientes portadores de deficiência, familiares e prestadores uniram-se para a manutenção das ações e organizaram manifestações de rua expressivas e marcantes.

A exclusão do catálogo das açōes significaria, além da desproteção, importante ameaça aos mercados de trabalho destes grupos. O sistema de atenção à saúde é, ao mesmo tempo, um ramo importante da economia, o que pode também ser tido como fator adicional de sua base social de sustentação. O sistema de saúde é mercado de trabalho essencial e, até o momento, em expansão. ${ }^{347}$

A leitura atenta das Leis de Reordenamento (NOGs) possibilita também depreender, em uma série de detalhes, como as regras são construídas de modo a compatibilizar os diversos interesses, inclusive pequenos interesses particulares. A incorporação de propostas dos atores sociais do campo oponente pode ser também observada na lei aprovada, como é o caso das novas formas de organização da atenção, proposição das Caixas e DGB.

3 Mi Muitos municípios (balneários) têm economia com base em turismo de saúde. Com a exclusão do catálogo destes benefícios, não apenas os empregos diretos nas casas de repouso estariam em jogo, como também de boa parte daqueles do comércio, restaurantes etc.

347 Entre 1970 e 1986 foram criados 600 mil novos postos de trabalho na área da saúde, estimando-se que empregue mais de $10 \%$ de toda a populaçĩo alemã ocupada (Eberle, 1998). 
Tais observaçōes corroboram as análises de diversos autores (Pierson, 1995; King, 1988) quanto à importância de diferentes grupos de interesses específicos na constituição de base ampliada de sustentação e como barreiras à retração dos programas sociais.

Conclui-se que, se a privatização não foi tão drástica quanto, já que o catálogo se manteve único e amplo, tal fato deveu-se à influência dos atores sociais que seriam atingidos de imediato. Ao mesmo tempo, semelhante ascendência dos atores se exerce dentro de limites claros. Ainda que a formulação da política se processe também via influência de grupos organizados, o poder do Estado é posto em prática. Existe hierarquia. A atuação dos atores está condicionada por limites estruturais do estado capitalista e sua influência está delimitada pelas constelações de atores em situaçāo e pelos diferentes status políticos conferidos a cada um.

\section{Evidências da política de clientela}

O modo corporativo de organização de interesses não prescinde da contemplação de interesses eleitorais imediatos. A política conservadora-liberal envolveu também interesses eleitorais de clientela política (Wanek, 1994; Deppe, 1998a; Gerlinger, 1997). O partido liberal (FDP) não é apenas 'o defensor da livre economia de mercado', representa também interesses dos profissionais liberais. Em particular, médicos e dentistas fazem parte de sua clientela. Por tal razão, este partido dificilmente se dispõe a concordar com qualquer alteração que acarrete maior regulaçāo das atividades dos médicos credenciados ou perdas financeiras. Tanto é a aprovação da Lei da Estrutura da Saúde, que incidiu sobre interesses destes prestadores, dependeu da conformação da 'grande coalizão' entre social-democratas c democrata-cristãos e da exclusão dos liberais, que participavam então do governo.

A política de clientela, como referido anteriormente, ficou evidente durante a implementaçāo da Lei da Estrutura da Saúde, levando à abolição de controle sobre produtores e prestadores. Na terceira fase da reforma, os interesses de médicos e dentistas foram novamente contemplados. Como recompensa pela aceitação, por parte dos médicoś, de controle na expansão do volume de ações prestadas, por meio do novo sistema de pagamento por casos atendidos, aboliu-se a definiçāo de tetos orçamentários para os gastos setoriais. ${ }^{348}$

A política de clientela é citada somente para salientar que os objetivos de contenção ao interior do próprio campo conservador-liberal estiveram condicionados por interesses da política miúda. As opções de contenção também sāo clientelisticamente motivadas, como é o caso da renúncia ao esgotamento de todas

348 A organização corporativa faz com que os interesses adquiram dependência em relação ao sistema, o que os torna não imediatamente correspondentes aos interesses individuais dos membros da organização. 
as reservas de economicidade e ao potencial de racionalização do sistema - um dos itens da perspectiva política liberal conservadora - para nāo ir contra interesses dos prestadores.

\section{Apranjos corporativos: pedefinição dos âmbitos e de graus de liberdade de ação}

A principal fonte de influência dos atores sociais, para além de diferentes formas possíveis de pressão de grupos de interesse envolvidos, está no modo de regulação do sistema de seguro social por meio de sua estrutura corporativa. No modelo alemão, o Estado delega a regulação de determinado setor da sociedade, por intermédio de arranjos corporativos, aos atores imediatamente envolvidos, atribuindo-lhes status público e inscrevendo seus interesses no próprio sistema (Schmitter, 1974; Lehmbruch, 1996; Döhler \& Manow, 1995a; Offe, 1994).

Entre os prestadores, os médicos sobressaem não apenas pela sua capacidade de influência, mas pela forma diferenciada de articulação de seus interesses. A atenção ambulatorial, por meio das Associações de Médicos das Caixas, é o setor da atenção à saúde em que são mais difundidos os arranjos corporativos característicos da proteção social alemã. Estas Associações possuem bem desenvolvidas as quatro dimensões sugeridas por Offe (1994) para a análise do corporativismo: (1) status de recursos: os recursos são, em boa parte, supridos pelo Estado, pois são organizaçōes de direito público e de filiação compulsória; (2) status de representação: é organização exclusiva de representação dos médicos credenciados e sua área de atuação é definida publicamente; (3) status de organização: suas relações internas são reguladas publicamente; (4) status de procedimento: são investidas do direito de auto-administraçāo (Offe, 1994).

Em razão da estrutura corporativa, os resultados da negociação entre estas organizações de interesses de nível intermediário nãó correspondem apenas aos interesses imediatos dos envolvidos. Os interesses são dependentes porque incluídos no sistema, o que os torna não imediatamente correspondentes aos interesses individuais dos membros da organização.

As leis aprovadas na terceira etapa, assim como a Lei da Reforma do GKV 2000 , terão repercussōes também sobre estes arranjos corporativos, pois redefiniram regras e mudaram competências dos órgăos de administração autônoma.

No processo de contenção desencadeado pela coalizão conservadora-liberal, durante os anos 90, buscou-se ampliar os espaços de atuação da chamada administração autônoma simultaneamente à retração das responsabilidades do Estado. Esse processo, contudo, foi comandado pelo Estado, que definiu as condições da atuação da administração dentro de limites estritos de contenção. Respon- 
sabilidades públicas foram transferidas a provedores e prestadores, reforçando o esquema neocorporativo característico da organizaçāo do Seguro Social de Doença alemão, ao mesmo tempo em que foram definidas condições mais estritas para sua atuação. Transferiram-se competências a outros agentes de regulação e redefiniram-se propósitos e objetivos da regulaçāo, reduzindo-se os graus de liberdade de atuação dos arranjos neocorporativos. ${ }^{3.9}$

Naquele processo, a delegação de competências estatais aos órgāos de administração autônoma conjunta não significou ampliação de seus espaços de negociação e graus de liberdade de ação. As possibilidades de ação foram, de antemão, canalizadas segundo objetivos políticos da coalizão governamental. A política neoconservadora continha uma série de dispositivos legais que deveria garantir que a ampliaçāo da competição incorresse na privatização do risco de adoecer e que os interesses dos prestadores não fossem contidos substancialmente.

Deste modo, as medidas implementadas e a capacidade de intervenção estatal observada na terceira etapa não podem ser relacionadas diretamente às proposições neoliberais de 'menos Estado', de retração do Estado ou de Estado mínimo (Stegmüller, 1996; Gerlinger, Giovanella \& Michelsen, 1997). Embora o discurso seja de desregulação, abolindo-se alguns procedimentos, o Estado intervém para modificar as formas de regulação. ${ }^{330}$ Mais do que diminuição da intensidade e abrangência da regulação, há mudança de ênfase da regulação no sentido de introduzir mecanismos de mercado no Seguro Social de Doença. Tem lugar uma redefinição das relações entre mercado e Estado (Deppe, 1995; Neubauer, 1996). Pode-se, assim, concordar com a tese de Borchert (1995) a respeito da transformação conservadora dos welfare states, que afirma que as políticas conservadoras podem ter reduzido o bem-estar, mas não prescindiram do Estado. Ao contrário do preconizado pelos liberais, que propugnam a retirada do Estado, a intervenção estatal se exerceu com determinação.

As leis mais recentes, além de indicar mudanças na conduçāo também mostram a capacidade de regulação e intervenção estátal nos processos políticos. Desse modo, não é possível falar apenas em corporativização do sistema de saúde como preconizado por alguns autores (Döhler \& Manow-Borgwardt, 1992). A intervenção do Estado não reduz-se à definição das possibilidades de ação e da competência decisória dos atores, à conformação do meio ambiente para tomada de decisāo.

349 A vigilância estatal permanece por meio de diversos mecanismos e órgãos. Em termos analíticos, pode-se dizer que a vigilância não é sobre a finalidade de 'interesse geral', de garantia de proteção social como a do 'Estado nacional keynesiano'. A vigilância principal é sobre a estabilização das taxas de contribuição, sobre a garantia dos interesses econômicos de um 'Estado competitivo nacional' (nationalen Wettbewerbsstaat) (Alvater, 1994a).

350 Intervenção estatal seria a ação estatal pontual $\mathrm{e}$ com prazo determinado $\mathrm{cm}$ processo econômico, com o intuito de corrigi-lo, direcionando-o a objetivos especílicos. A regulação estatal, por sua vez, é entendida como forma de influenciar o processo em questăo de forma duradoura. A intervenção afeta a competência de condução dos atores corporativos (Neubauer; 1996). 
Para Döhler \& Manow-Borgwardt (1992), a intervenção estatal na política de saúde objetivaria apenas possibilitar a autocondução do sistema pelas organizações setoriais, política na qual o Estado teria obtido sucesso na década de 80 , uma vez que teria alcançado mudar as formas de atuação dos atores. O Estado teria transferido competências e definido regras de tomada de decisāo para as organizaçōes setoriais, redefinindo a constelaçāo de atores, e estas teriam encaminhado as reformas necessárias, no sentido de conter gastos, conforme os objetivos pretendidos pelo mesmo.

Durante a década de 90 , contudo, não apenas o contexto, mas também o conteúdo da política foram definidos pelo Estado. Tanto a Lei da Estrutura da Saúde (GSG), quanto a terceira fase da reforma e a Lei da Reforma do GKV 2000 têm fortes componentes de intervençāo hierárquica. A GSG, na versāo original, significou importante intervenção contra o interesse dos médicos e da indústria farmacêutica, a terceira etapa definiu a privatização parcial dos riscos, e a Reforma 2000 interveio em interesse de prestadores, reforçou a posiçāo das Caixas frente a produtores de insumos e modificou o modo de condução corporativa, quebrando o monopólio das Associações de Médicos das Caixas.

Pode-se afirmar que, por um lado, se o sistema de proteção à saúde alemāo é impregnado pelos mecanismos de concertação neocorporativa, modelo segundo o qual o Estado renuncia a medidas unilaterais e delega a responsabilidade da solução de conflitos e problemas de condução a organizações hierárquicas e de pertencimento obrigatório de fato ou de direito, atribuindo-lhes funçōes públicas e tornando-as participantes na formulação das opções políticas; por outro lado, transparece também a capacidade de intervenção estatal no processo político de reformas recentes do $\mathrm{GKV}^{351}$ Ocorrem mudanças no modo de condução da política que passa a ocorrer tanto por meio da negociaçāo corporativa, quanto por ordenação hierárquica. A capacidade de intervenção estatal mostra-se na redefinição dos arranjos neocorporativos e na definição do conteúdo da política.

A nova correlação de forças com a vitória eleitoral da social-democracia, por sua vez, possibilitou nova condução do processo, redirecionando-o para o enfrentamento de problemas relativos à qualidade e organização da atenção, colocando aspectos restritivos em segundo plano.

351 A manifestação de clara hicrarquia na formulação da política limita o alcance das teses sobre erosão do Estado. Uma implicação importante da tese de erosão do Estado nacional, com conseqüências práticas imediatis, é a afirmação da impossibilidade de intervenção estatal, Dizer que o Estado erodiu significa afirmar que o Estado nāo teria mais capacidade de direcionar as políticas sociais e econômicas. Sem negar as importantes transformaçōes econômico-sociais da atualidade, o apelo à incapacidade de intervenção do Estado é álibi fácil para governos dos países de industrialização recente, como o nosso, se esquivarem de tentativas de políticas mais soberanas e mais voltadas aos interesses populares. 
Para concluir a análise das estratégias de contenção, pode-se asseverar que as medidas selecionadas na Alemanha, embora tenham similaridades com aquelas propostas em outros países, adquirem uma forma de aplicação particular, ditada pelas especificidades da institucionalidade do GKV e da organização da atenção à saúde, em particular, a forma de inscrição de interesses e atores na institucionalidade do sistema.

A bibliografia selecionada, ao dar conta do debate alemão referido à ampliação da competição e mecanismos propostos, elucida, por sua vez, as implicações negativas da introdução de mecanismos de mercado ao interior de um sistema de proteção que se quer solidário, especialmente a seleçāo de riscos e a privatização parcial dos mesmos. Aponta para o fato de que a competiçāo entre seguradoras estimula a seleção de riscos e que a competição entre prestadores pode incorrer em subatenção, ambas aprofundando iniqüidades.

A maioria dos autores que discute o problema da introdução da competição na Alemanha alerta para os efeitos deletérios da concorrência para a proteção social ao risco de adoecer, da mesma forma que chama a atenção para as especificidades do sistema de saúde alemão e de seu modelo de proteção, que atenuariam estes resultados. Semelhantes efeitos não seriam imediatos nem estariam garantidos. Resultariam de mudanças cumulativas a longo prazo não só da organização do sistema de proteção e atenção, mas também culturais - de valores morais e representações sociais. Os presumíveis efeitos da competição seriam alterados não apenas pelos mecanismos e garantias específicas diretamente introduzidos para evitar a competição predatória, mas pelas características fundamentais do sistema alemão.

Sem dúvida, as reformas neoconservadoras acarretam restriçōes e tendencialmente produzem aumento das desigualdades, mas sua aplicação não traz consigo todos os resultados que uma análise descontextualizada poderia prever. No caso alemāo, a competição introduzida é limitada, sendo acompanhada de amplo mecanismo de compensação financeira de riscos para evitar competição predatória e reduzir as possibilidades de seleção de riscos. Da mesma forma, a opção neoconservadora é claramente favorável a medidas mais diretas de privatização parcial dos riscos, mas a introdução e aumentos de co-pagamento são acompanhados de regras que previnem efeitos deletérios desta medida sobre os grupos mais vulneráveis (camadas de baixa renda, doentes crônicos e crianças) e definem um limite máximo de acometimento da renda para a participação financeira direta dos contribuintes. Deste modo, a tradiçāo de solidariedade, princípio constitutivo do seguro social, condiciona as propostas neoconservadoras.

Certa convergência de medidas de contenção, por conseguinte, não traz necessariamente o mesmo tipo de resultados como conseqüência. As especificidades com que as medidas de contenção foram aplicadas no caso alemão indicam que, 
embora medidas similares de contenção possam vir a ser implementadas em diversos países, os resultados de sua implantação não podem ser predefinidos de forma genérica. ${ }^{352} \mathrm{O}$ grau, extensão e forma em que as medidas são postas em prática e, em conseqüência, o impacto que produzem, sāo condicionados tanto por aspectos culturais que definem certas preferências nacionais, certas escolhas, como pelo aparato institucional prévio, formas de organização e de articulaçāo de interesses e constelações de atores envolvidos.

No caso alemão, a institucionalidade do seguro social, sua forma de organização e as formas de regulaçāo do sistema de características neocorporativas, onde atores e interesses estão inscritos na própria institucionalidade setorial, tem correspondência com a própria forma de organização política da sociedade alemã, condicionando, de forma mais incisiva, as mudanças e limitando a abrangência das políticas de contenção. A ampla aceitação da solidariedade, a estrutura neocorporativa bem desenvolvida ao interior do sistema e a tradição reguladora do Estado alemão são aspectos importantes que moldaram tais resultados.

Dando continuidade à análise das reformas, na discussão final apresentada a seguir, serão analisados os impactos das políticas de contenção na proteção à saúde e as possíveis repercussões das medidas implementadas nos princípios constitutivos do Seguro Social de Doença alemão.

352 As especificidades da proteção e da implementação de medidas de contençāo no caso alemão demonstradas neste estudo sugerem baixa probabilidade de ocorrer uma homogeneização da proteção social nos diversos países como conseqüência da 'globalizaçāo' da economia. 